Article

\title{
The Tocantinzinho Paleoproterozoic Porphyry-Style Gold Deposit, Tapajós Mineral Province (Brazil): Geology, Petrology and Fluid Inclusion Evidence for Ore-Forming Processes
}

\author{
Adriana Araújo Castro Lopes ${ }^{1, *}$ and Márcia Abrahão Moura ${ }^{2}$ \\ 1 Campus Universitário de Juruti, Universidade Federal do Oeste do Pará, Juruti 68170-000, Brazil \\ 2 Instituto de Geociências, Universidade de Brasília, Campus Universitário Darcy Ribeiro, Brasília 70910-900, \\ Brazil; mamoura@unb.br \\ * Correspondence: adriana.castro@ufopa.edu.br
}

Received: 2 November 2018; Accepted: 27 December 2018; Published: 5 January 2019

\begin{abstract}
The Tocantinzinho gold deposit, located in the Tapajós Mineral Province, Amazonia, Brazil, is considered the largest gold deposit in the region. It is a stockwork-disseminated gold deposit, hosted in a $1982 \pm 8$ Ma hydrothermalized monzogranite of the Creporizão Intrusive Suite, with petrographic and geochemical characteristics of volcanic arc to post-collisional granites. Gold is mainly associated with phyllic alteration. Primary fluid inclusions trapped in the mineralization stages are $\mathrm{H}_{2} \mathrm{O}-\mathrm{NaCl}$ and unsaturated and homogenize either to the vapor or to the liquid with $\mathrm{Th}_{(\mathrm{t})}$ of $300-430{ }^{\circ} \mathrm{C}$, salinity of $2-16 \mathrm{wt} \% \mathrm{NaCl}$ eq. and density from 0.43 to $0.94 \mathrm{~g} / \mathrm{cm}^{3}$. At these conditions, $\mathrm{Au}$ is expected to be transported as $\mathrm{Au}(\mathrm{HS})_{2}{ }^{-}$complexes and ore is deposited as the result of boiling in the first mineralizing stages and of mixing between magmatic fluid and meteoric water during the phyllic alteration. Compared with other deposits, Tocantinzinho has similarities with magmatic-hydrothermal oxidized calc-alkaline granite-related gold deposits classified as porphyry gold deposits but we classify as a porphyry-style gold deposit, as it lacks some characteristics of the Phanerozoic porphyry-type deposits. The results from this study can be used to elaborate and guide prospection models in Amazonia and in similar Proterozoic terrains.
\end{abstract}

Keywords: gold; hydrothermal alteration; fluid inclusions; porphyry; Tapajós Mineral Province

\section{Introduction}

Located in the Tapajós Mineral Province (TMP) (Figure 1), Tocantinzinho is a stockwork gold deposit showing evidence of hydrothermal alteration. The Brazilian province lies in the Amazonian Craton and includes the southwest portion of the state of Pará and part of the southeast region of the state of Amazonas. According to some studies, it extends to the north of Mato Grosso State [1,2]. Tocantinzinho is part of the Ventuari-Tapajós geochronological province [3] or part of the Parima-Tapajós Paleoproterozoic orogenic belt [4]. Several gold deposits can be found to the north of the province alongside the Jamanxim and Crepori rivers but currently, considering its gold production, Tocantinzinho is considered the largest gold deposit in the region, with estimated annual production of 4.3 tons milled, an Au grade of $1.42 \mathrm{~g} / \mathrm{t}$ and $170.000 \mathrm{oz}$ of gold production/year [5-7].

Geological mapping programs run by the Brazilian Geological Survey (Minerals Research and Resource Company/CPRM) and collaborators have produced a better geological understanding of the province [5]. Academic papers from universities and research institutes-most of them dedicated to studying specific mineral deposits-have also contributed to increased knowledge about the region [8-19]. 


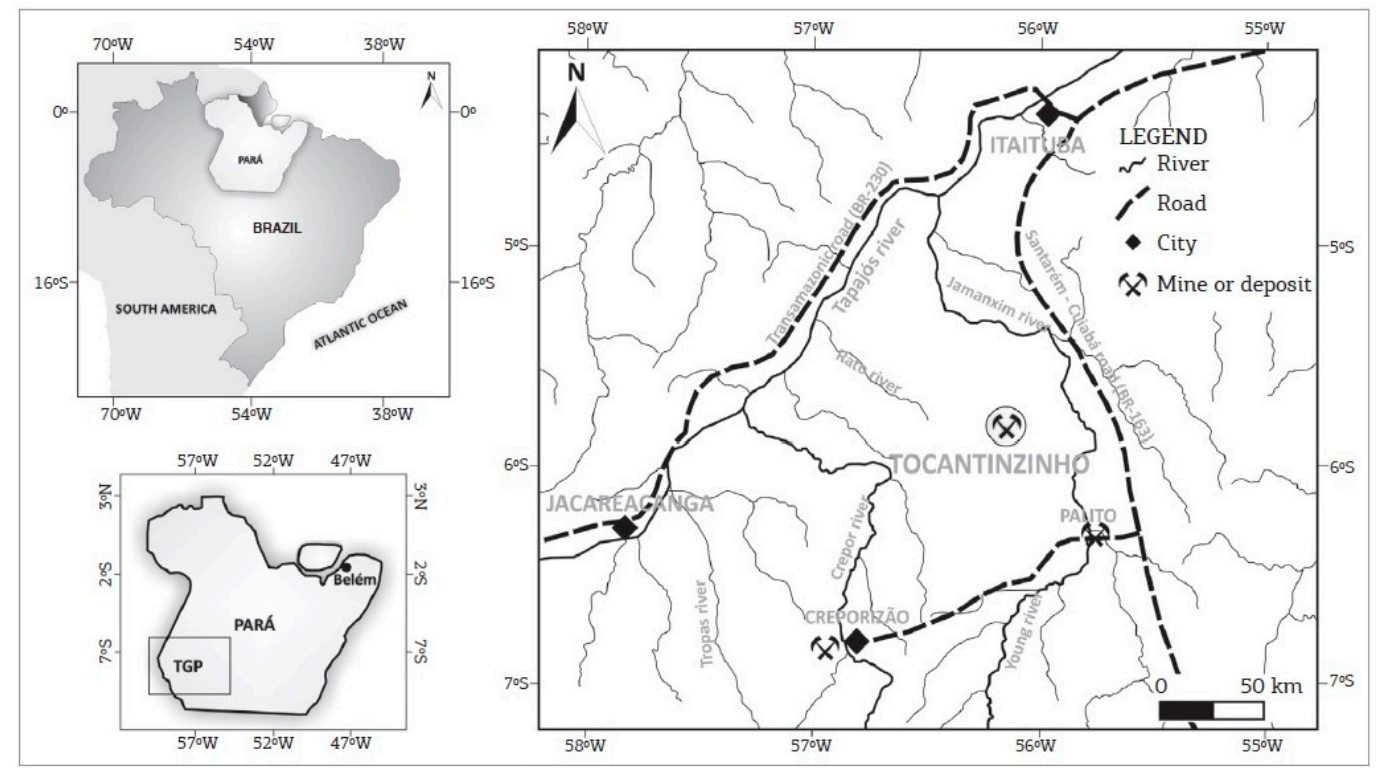

Figure 1. Location map of Tocantinzinho Gold Deposit [8].

The geological characteristics of the Tapajós region and the similar Northern Mato Grosso region point to the existence of Proterozoic magmatic arcs, which may have played an important role in the formation of gold deposits of different styles, including deposits related to granitic intrusions or to epithermal zones [5,20]. Various studies that have been conducted regarding the Tocantinzinho deposit have proposed different genetic models, such as reduced intrusion-related gold systems [8,21-24].

This paper presents new geological, petrological and fluid inclusion data that help to constrain the nature and origin of the hydrothermal fluids of the Tocantinzinho deposit. These data were used to elaborate a new metallogenic model for Tocantinzinho gold deposit and should contribute to improving gold prospection in the Tapajos Mineral Province and other similar Proterozoic regions in Brazil and worldwide.

\section{Materials and Methods}

The present study summarizes work conduced over two different field campaigns. We selected 44 thin sections from 11 representative drill-holes for detailed geological and petrographic study. All thin sections were carefully checked under transmitted and reflected light microscopes (Brasilia, Federal District, Brazil) at the Federal University of Pará (UFPA) and the University of Brasília (UnB) using a Zeiss Axioplan 2 petrographic microscope (Zeiss, Oberkochen, Germany). Eighteen samples of country and host rocks were selected for whole-rock chemical analyses of major and trace elements, performed at Acme Analytical Laboratories Ltd. (Vancouver, BC, Canada) using routine laboratory standards. The major elements were determined using inductively coupled plasma-atomic emission spectroscopy (ICP-AES), whereas trace elements were determined with inductively coupled plasma-mass spectrometry (ICP-MS). Loss of ignition was determined by calcination at $1000{ }^{\circ} \mathrm{C}$; the granitic rocks used for petrological diagrams and interpretation have loss of ignition lower than $2 \mathrm{wt} \%$.

Minerals were chemically analyzed at two different laboratories: feldspar, chlorite, muscovite, rutile and titanite were analyzed in JEOL-JXA8600 (Jeol, Peabody, MA, USA) at the University of São Paulo; and pyrite, chalcopyrite, sphalerite, galena, altaite, gold and chlorite were analyzed in JXA-8230-Jeol electron microprobe at the University of Brasilia (Jeol, Peabody, MA, USA), running at $15 \mathrm{kV}$ and $15 \mathrm{nA}$, with spot sizes of 1-10 $\mu \mathrm{m}$, depending on the mineral size and type. The standards employed were synthetic and natural substances commercially supplied by CAMECA company.

Hydrothermal temperature was estimated using a chlorite empirical geothermometer [25] and later compared with fluid inclusions results. The data are based on the cationic ratio of the chlorite 
tetrahedral aluminum $\left(\mathrm{Al}^{\mathrm{IV}}\right)$, allowing the calculation of temperature from the following equation: $\mathrm{T}\left({ }^{\circ} \mathrm{C}\right)=321.98 \times(\mathrm{Al} \mathrm{IV} / 2)-61.92$.

Fluid inclusions were studied using a Zeiss petrographic microscope, Axioskop 2 model (Zeiss, Oberkochen, Germany). The microthermometric study was performed in the Fluid Inclusions Laboratory of the Geosciences Institute at the University of Brasília. Approximately 200 fluid inclusions were analyzed. Phase change temperatures were measured using a Linkam THMSG600 (Linkam Scientific, Tadworth, UK) coupled with an Olympus BX-60 microscope (Olympus Life Science, Township, PA, EUA). Calibration of the equipment was performed by measurements of $\operatorname{Tm}_{(\mathrm{CO})}\left(\mathrm{CO}_{2}\right.$ melting temperature), $\mathrm{Tm}_{\text {(ice) }}$ (ice melting temperature) and $\mathrm{Th}_{(\mathrm{H} 2 \mathrm{O})}$ (pure water homogenization temperature) in synthetic fluid inclusions from Fluid Inc. The margin of error was $\pm 0.1^{\circ} \mathrm{C}$ for cooling and $\pm 1{ }^{\circ} \mathrm{C}$ for homogenization temperatures over $200^{\circ} \mathrm{C}$. Salinity and density values were estimated using the equation for $\mathrm{H}_{2} \mathrm{O}-\mathrm{NaCl}$ systems presenting low to moderate salinities [26,27].

\section{Geological and Petrological Characterization of the Tocantinzinho Deposit}

\subsection{Geological Context of the Tapajos Province}

The Tapajós Mineral Province is interpreted as part of the Tapajós-Parima or Ventuari-Tapajós geochronological province $[3,4,28,29]$. It is geologically limited to the east by the Central Amazon Province of the Paleoproterozoic and to the west by the Rio Negro (Guiana Shield) and Rondonia-Juruena (Central Brazil Shield) provinces, both of which are assigned as Mesoproterozoic [30] (Figure 2). There is much controversy about the regional geology in the literature.

Two orogenic events were responsible for the formation of the Tapajos Mineral Province, which occurred between 2.10 and 1.87 Ga: Mundurucus (2040-957 Ma) and Tropas (1906-1886 Ma) [31]. The Mundurucus Orogeny began with island arc magmatism and turbidite sedimentation in a retroarc or oceanic basin. In this case, well-preserved structures in the rocks of the central-eastern portion are recognized in the NE-SW direction, from the schists of the Group Jacareacanga to the gneisses of the Cuiú-Cuiú Complex. The second deformation event was of brittle-ductile character in NW-SE transverse shear zones, with high angle and dextral kinematics, which were responsible for the placement of high-to-medium potassium calcium-alkaline plutons from the Creporizão and Tropas suites. The Creporizão suite has been described as a calc-alkaline batholith of granitic composition, emplaced along the regional shear trend of NW-SE [32]. U-Pb zircon aged $1957 \pm 6 \mathrm{Ma}$, obtained for a granite attributed to the Creporizão magmatic suite, intruded in a magmatic arc tectonic setting $[31,33]$. The Tropas intrusive suite was assigned to granites of $1892 \pm 6$ Ma in the Tapajós Province [28,33,34].

The igneous events were also characterized by mafic magmatism, especially the high- $\mathrm{K}$ calc-alkaline gabbroic rocks of the Ingarana Intrusive Suite [28].

Several units interpreted as intracratonic were then formed and only affected by brittle deformation. Among them are the Iriri Group and the Maloquinha Intrusive Suite, both aged $1.87 \mathrm{Ga}$ and related to the Uatumã volcano-plutonic event. The Bom Jardim Formation (1881 Ma) is composed by volcanoclastic rocks, lamprophyres, andesites and dacites.

Buiuçú Formation and the Palmares Group are the result of installation of Paleoproterozoic continental rifts in the Tapajós domain that culminated with the deposition of siliciclastic sedimentary covers. The dikes and sills of the Crepori Diabase crosscut the Orosian basement and are aged $1780 \pm 7 \mathrm{Ma}$, which, besides dating this magmatic event, indicates the minimum deposition age of the Paleoproterozoic sedimentary sequences. The troctolites of the Cachoeira Seca Intrusive Suite (1186 $\pm 12 \mathrm{Ma} / \mathrm{U}-\mathrm{Pb}$ Sensitive High Resolution Ion Microprobe-SHRIMP—on baddeleyite crystals) mark the reactivation of the mantle under the Tapajós domain after a quiescent period of about $600 \mathrm{Ma}$. This event was interpreted as a Stenian alkaline magmatism related to continental rifts-a reflection of the Sunsás orogeny. 


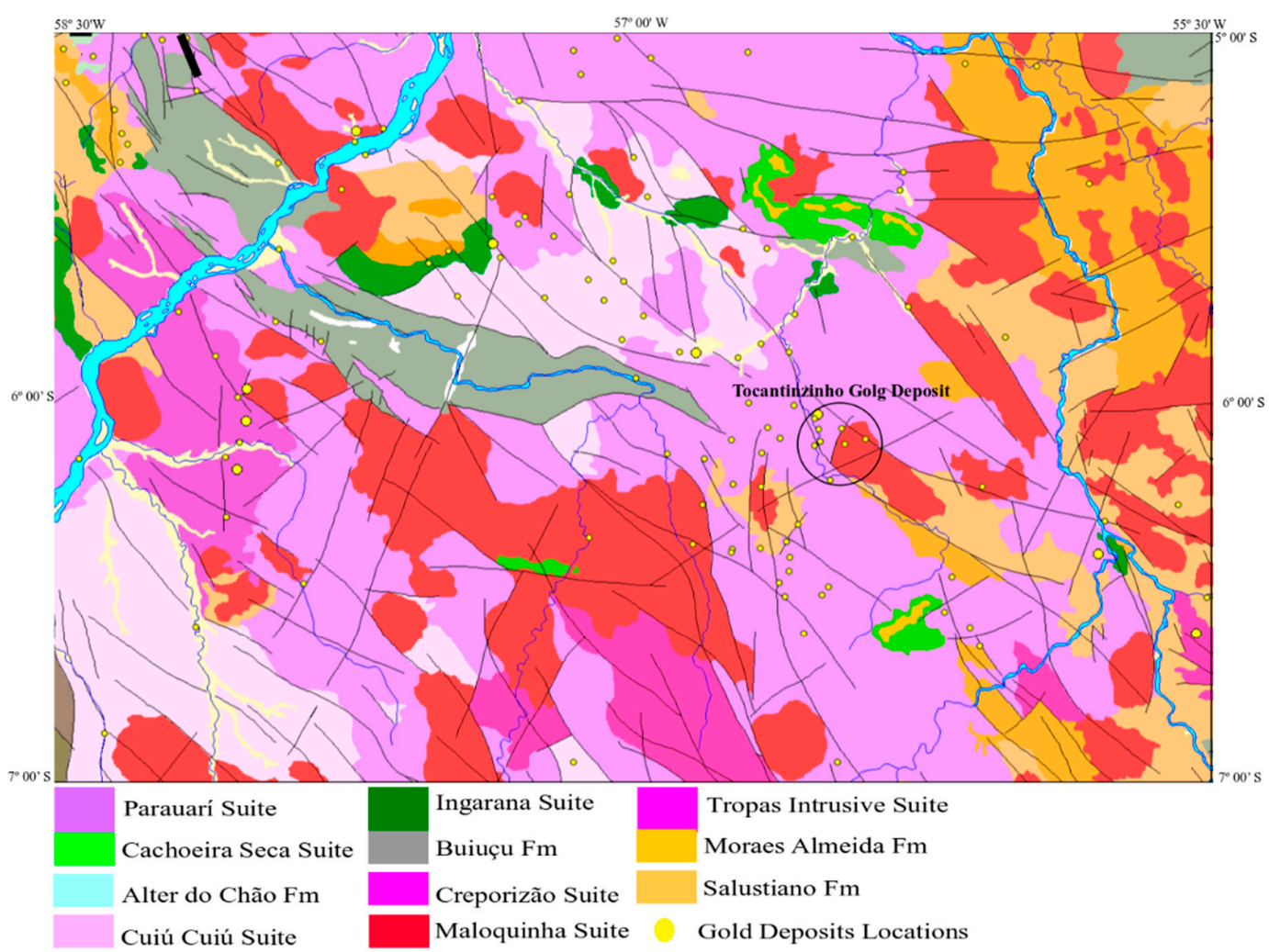

Figure 2. Geologic map showing part of Tapajós domain, including the Tocantinzinho deposit. Adapted from [30].

The structural evolution of the TMP began with a ductile to ductile-brittle compressive event that imprinted a NE-SW-trending foliation in the rocks of both the Jacareacanga Group and the Cuiú-Cuiú Complex $[35,36]$. This event was responsible for the most prominent structures in the area, related to the development of sinistral NW-SE-trending transcurrent megalineaments, which controlled the emplacement of the Creporizão, Tropas and Parauari suites. The other extensional tectonics (E-W, NE-SW) would have been affected by the reactivation of old weak crustal zones or by the emplacement of the Maloquinha Intrusive Suite.

\subsection{Local Geology}

The Tocantinzinho deposit is hosted in a monzogranite of $1982 \pm 8 \mathrm{Ma}(\mathrm{Pb}-\mathrm{Pb}$ in zircon) attributed to the Creporizão intrusive suite $[8,37]$. The monzogranite has been subjected to intense hydrothermal alteration. As a result, altered granite and hydrothermal rocks-in which mineralization is hosted-were produced. Mafic and felsic dikes also occur in the area.

The geological map of the Tocantinzinho deposit (Figure 3) shows the lithostratigraphic units that occur in the Tocantinzinho area and in other nearby deposits [38,39]. The studied rocks do not present deformation or preferred orientation. Brecciated rocks are recognized in the deposit area. The elongated geometry of the Tocantinzinho granite and related rocks, features of solid-state deformation within granites and syntectonic deformation of andesitic dikes, imply the existence of wrench-type tectonic control for the deposit area [37].

In the area, monzogranite is the dominant rock, which has been mostly altered into two hydrothermal varieties: one with strongly reddish to pinkish coarse K-feldspar crystals associated with equally coarse milky quartz crystals, informally called Salame; and the other is distinguished by its greenish tone with gray to whitish hues, with the informal name Smoky. Subordinate aplites, most likely co-magmatic, have been also recognized. 


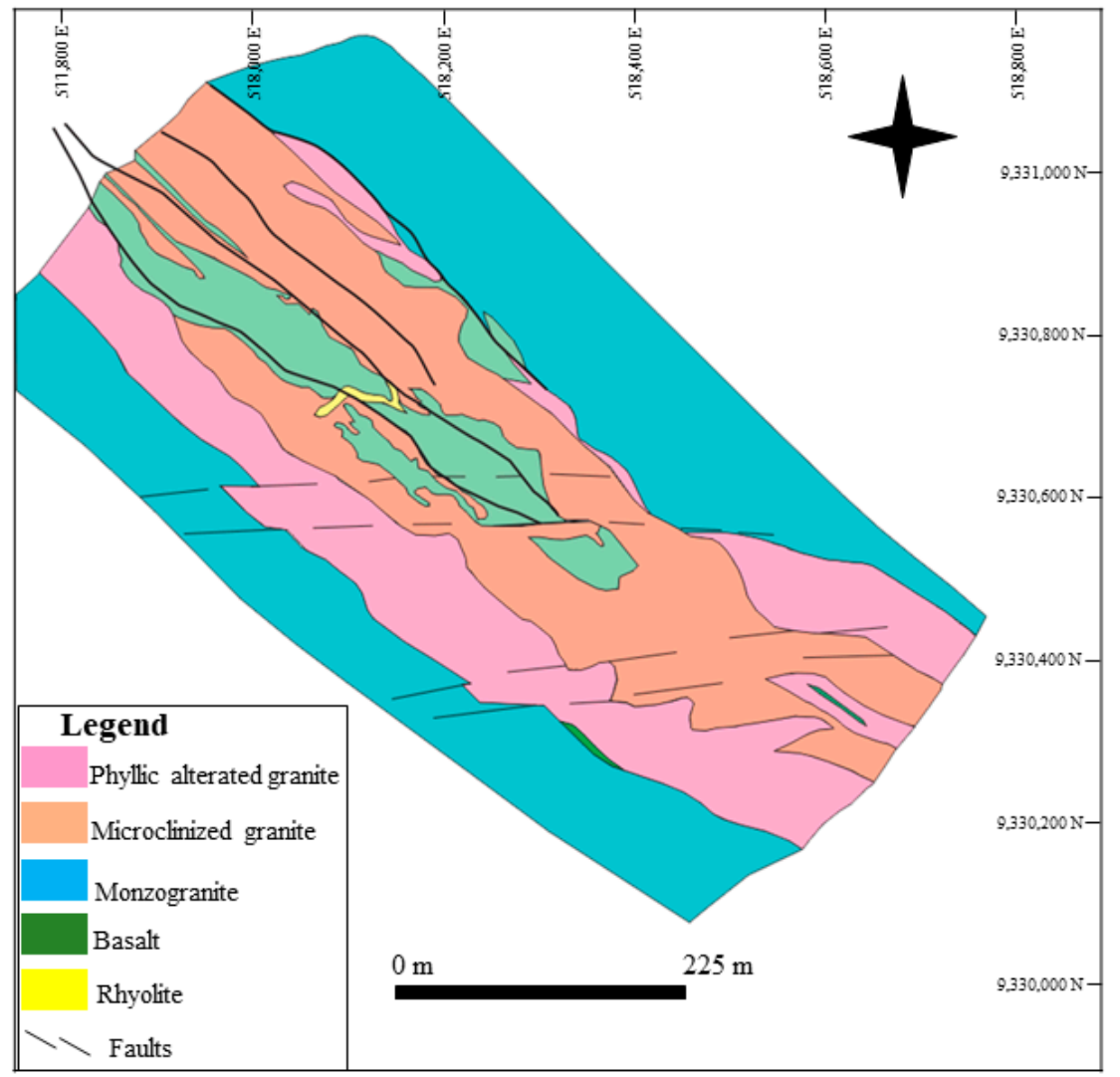

Figure 3. Geological map of the Tocantinzinho deposit. Modified from Juras et al. [7].

Mafic dikes form a quite eroded body, which partially covers the mineralized zone and seems to taper and converge at depth to possible conduits that acted as magma feeders. This body was pervasively altered by phyllic alteration, chloritization and carbonation.

Although the mineralized granite does not show evidence of ductile deformation; structurally, brittle features are recognized in planar arrangements, defined by NE-SW-trending and steeply-dipping sheeted veinlets containing chlorite and quartz. On surface mapping, a series of sinistral E-W faults were identified, mostly up to tens of meters long [7].

The hydrothermal alteration is present in all kinds of rocks, so that many primary features of the host granite in the mineralized zone can still be recognized. The different styles of mineralization in the host granite comprise sulphides in stockwork zones [6].

\section{Results}

\subsection{Petrography}

The essential minerals of the unaltered monzogranite are quartz (25-30\%), microcline (35-40\%), oligoclase (30-35\%) and biotite (3-5\%) [40]. The accessory minerals are zircon, titanite, pyrite and magnetite, which compose approximately $5 \%$ of the granite (Figure $4 \mathrm{~A}$ ). The secondary minerals are epidote, sericite and chlorite (approximately $3 \%$ ). The feldspars occur as subhedral crystals of medium size $(0.2$ to $1 \mathrm{~mm})$ and tabular habit. The quartz grains are anhedral, usually with coarse granulation ( 0.5 to $1 \mathrm{~mm}$ ), showing strong undulating extinction and sutured contacts, suggesting a weak recrystallization process. The biotite occurs as medium-to-fine lamellae or in veinlets ( 0.2 to $1 \mathrm{~mm}$ ) with reddish brown color. The accessory minerals occur dispersed in rock or included in biotite (zircon, magnetite and titanite). Chloritized biotite (5\%) is the varietal mineral. Primary magnetite was observed as an accessory mineral. Sericite, epidote and carbonates are alteration minerals (5\%). Quartz is present as medium-to-fine-sized grains $(0.5-1 \mathrm{~mm})$. Plagioclase crystals are medium size $(0.8-1 \mathrm{~mm})$ 
and are generally altered to sericite and carbonate. K-feldspar occurs as medium-sized crystals $(0.6-0.8 \mathrm{~mm})$ and is locally cut by veinlets. Chlorite occurs as a result of biotite alteration and filling fractures, forming single- or multiple-mineral veins. Carbonate is a hydrothermal alteration mineral, which fills fractures or replaces feldspar crystals. Hydrothermal pyrite and magnetite crystals-some altered to hematite-were also observed.

The felsic dikes have porphyritic, allotriomorphic and inequigranular textures and are altered and cut by veins (Figure $4 \mathrm{~B})$. The essential minerals are quartz (35\%), albite (30-35\%) and microcline $(20-25 \%)$.

The texture of the mafic dikes is medium-to-fine hypidiomorphic granular with medium-sized plagioclase phenocrysts $(0.6 \mathrm{~mm})$, immersed in a dark green aphanitic matrix (Figure $4 \mathrm{C}$ ). The estimate modal composition is: glassy matrix (40-45\%), plagioclase (15-20\%), amphibole (actinolite) (10-15\%), quartz (5\%), K-feldspar (5\%) and chloritized biotite (5\%). Chlorite, carbonate and sericite are secondary minerals (5\%). Magnetite, pyrite, chalcopyrite and sphalerite compose $2 \%$ to $3 \%$ of the rock.

\subsection{Lithogeochemistry}

The weakly altered to unaltered monzogranite shows an average composition of 70.97-72.89\% $\mathrm{SiO}_{2}$, moderate $\mathrm{MgO} / \mathrm{TiO}_{2}$ ratio of $1.06-2.79, \mathrm{~K}_{2} \mathrm{O} / \mathrm{Na}_{2} \mathrm{O}$ ratio of $1.38-2.29 \%, \mathrm{Al}_{2} \mathrm{O}_{3}$ of $11.33-14.23 \%$, $\mathrm{Na}_{2} \mathrm{O}$ with $2.57-3.87 \%$, low $\mathrm{CaO}$ at $0.39-1.51 \%$ and $\mathrm{MgO}$ of $0.31-1.25 \%$ (Table 1 ). They are classified as metaluminous to peraluminous in Shand's diagram and have petrographic and chemical characteristics of I-type calc-alkaline granite (Figure 5) [41]. The distribution patterns of trace elements show strong positive anomalies of $\mathrm{Rb}, \mathrm{Th}, \mathrm{Zr}, \mathrm{Hf}$ and $\mathrm{Y}$ and negative anomalies of $\mathrm{Sr}, \mathrm{P}, \mathrm{Nb}$ and $\mathrm{Ti}$. In the tectonic discrimination diagrams, the samples concentrate in the field of volcanic arc to post-collisional granites (Figure 6) [42]. The values were normalized to the chondrite of Nakamura [43]. The patterns are weakly fractionated with ratios $(\mathrm{La} / \mathrm{Yb})_{\mathrm{N}}$ of $12.23-16.40$ and exhibit a weak negative Eu anomaly (Figure 7). The felsic dike has a lower negative $\mathrm{Nd}$ anomaly and has negative Eu anomaly.

The microclinized rocks show values of $\mathrm{SiO}_{2} 59.84-75.49 \%, \mathrm{Al}_{2} \mathrm{O}_{3} 11.62-15.57 \%, \mathrm{Na}_{2} \mathrm{O} 3.05-4.95 \%$ and $\mathrm{CaO} 0.77-4.38 \%$ and $\mathrm{K}_{2} \mathrm{O} / \mathrm{Na}_{2} \mathrm{O}$ ratio of $0.62-1.62$. The phyllic-altered monzogranite exhibits $\mathrm{SiO}_{2}$ that ranges from $55.66 \%$ to $77.51 \% . \mathrm{TiO}_{2}, \mathrm{MnO}$ and $\mathrm{MgO}$ are relatively higher, at $0.22-1.09 \%$, $0.03-0.16 \%$ and $0.34-5.53 \%$, respectively, than in microclinized granites. $\mathrm{Al}_{2} \mathrm{O}_{3}$ and $\mathrm{Fe}_{2} \mathrm{O}_{3}(\mathrm{t})$ are higher in phyllic-altered rocks, with values of $11.91-16.06 \%$ and $1.75-6.15 \%$, respectively. However, the $\mathrm{K}_{2} \mathrm{O} / \mathrm{Na}_{2} \mathrm{O}$ ratio is lower than the microclinized granite, showing values of $0.18-1.45$.

The Harker variation diagram for trace elements shows the main patterns of altered samples in the Tocantinzinho deposit. The microclinized samples have higher values of Ba (473-1106 ppm), 91.4-638 ppm of Sr and 124-150.50 ppm of Rb, whereas these values are lower in the phyllic-altered samples: 144-1298 ppm of Ba, 66.1-714.5 ppm of Sr and 20.9-166.9 ppm of Rb.

Phyllic-altered samples exhibit higher concentrations of gold (9542.90 ppb) and copper (217 ppm), compared with the microclinized samples with Au present at $193.63 \mathrm{ppb}$ and copper at $29.40 \mathrm{ppm}$. The former are also rich in $\mathrm{Pb}, \mathrm{As}, \mathrm{Bi}, \mathrm{Cd}$ and $\mathrm{Zn}: 121.68,1.75,6.35,2.83$ and 278 ppm, respectively, compared with the latter, which are $9.77,3.23,0.5,0.0$ and $39.0 \mathrm{ppm}$, respectively. Most exhibit a moderated fractionation pattern of the Light Rare Earth Elements (LREE) and a negative Eu anomaly. For phyllic-altered samples, $\sum R E E=191.42$ and the ratio $(\mathrm{La} / \mathrm{Yb})_{\mathrm{N}}$ varies from 12.70 to 21.48. For the microclinized samples, $\sum \mathrm{REE}=196.96$ and the ratio $(\mathrm{La} / \mathrm{Yb})_{\mathrm{N}}$ vary from 12.01 to 40.80 (Figure 8). 


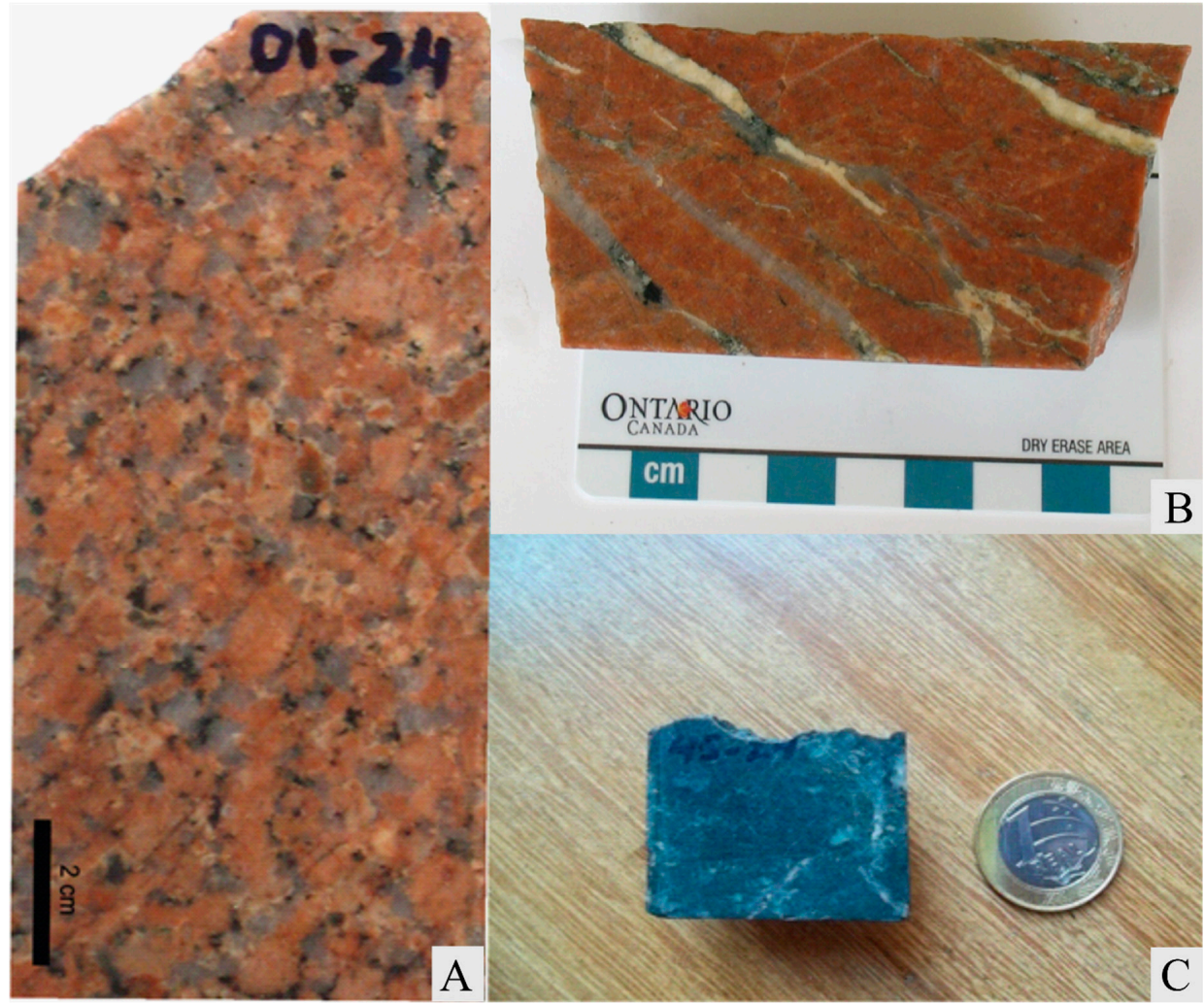

Figure 4. (A) Tocantinzinho monzogranite: the principal host rock of the Tocantinzinho deposit; (B) dike of rhyolitic composition; (C) mafic dike of basaltic composition.

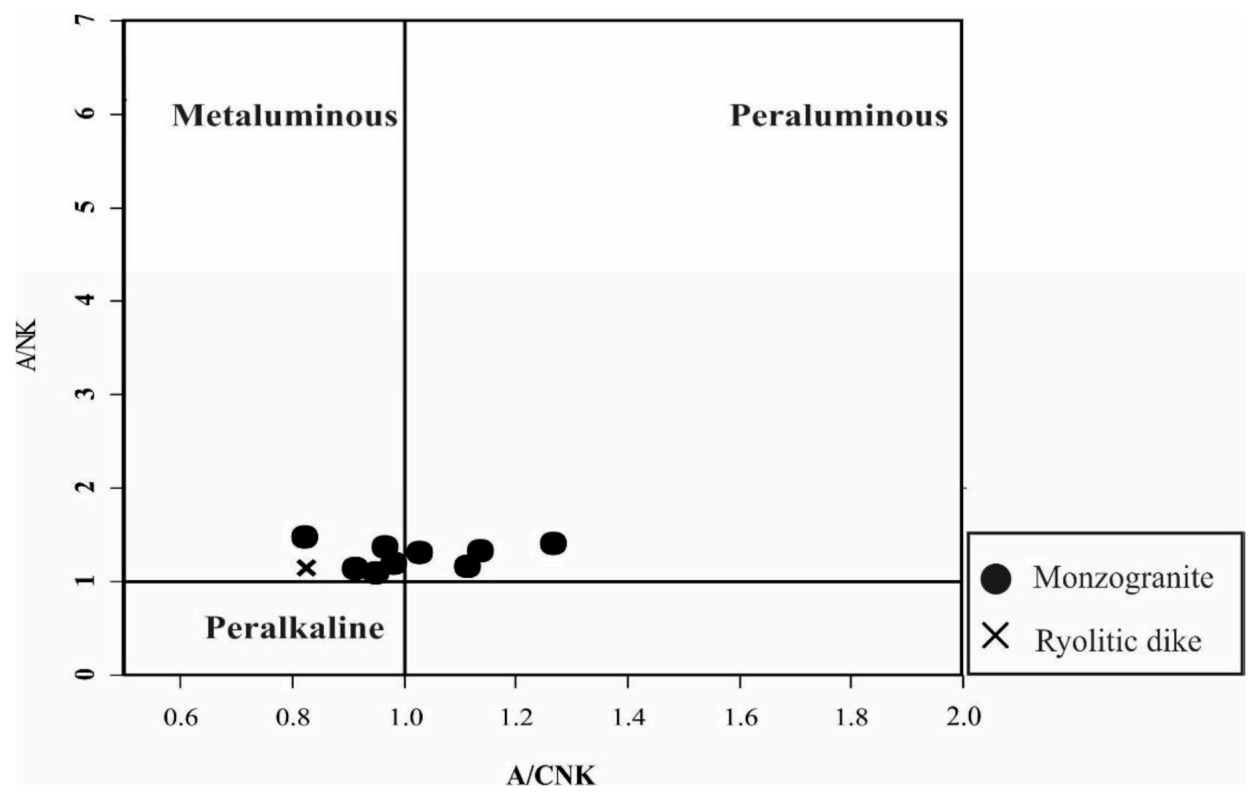

Figure 5. Alkalinity Diagram, showing the peraluminous to metaluminous nature of the most preserved samples of the Tocantinzinho deposit granites and the rhyolitic dike [41].

Based on the Totally-Alcali versus Silica (TAS) diagram [44], the mafic dike that cuts the granite rocks is composed of basalt. According to the tectonic environment diagram proposed by Pearce and Cann [45], it is classified as calc-alkaline basalt. The \#mg ([MgO/ $\left.\left(\mathrm{MgO}+\mathrm{Fe}_{2} \mathrm{O}_{3}\right)\right]$ is 0.45 , low to moderate and the nickel content is approximately $75.10 \mathrm{ppm}$. 
The tholeiitic magma mantle-derived rocks have \#mg higher than 0.68 and Ni content between 300 and $500 \mathrm{ppm}$, which suggests that the mafic dike represents differentiated mafic magma or possible crust contamination. According to the normalized spider diagrams proposed by Sun and McDonough [46], there is a strong positive anomaly of $\mathrm{Pb}$ and $\mathrm{Sr}$ and negative anomaly of $\mathrm{Ba}, \mathrm{Nb}$ and Ti. Low Ti and $P$ values in mafic dikes suggest a lithospheric mantle source [47]. The $\sum R E E$ is 93.16. Its pattern normalized to chondrite is weakly fractionated.
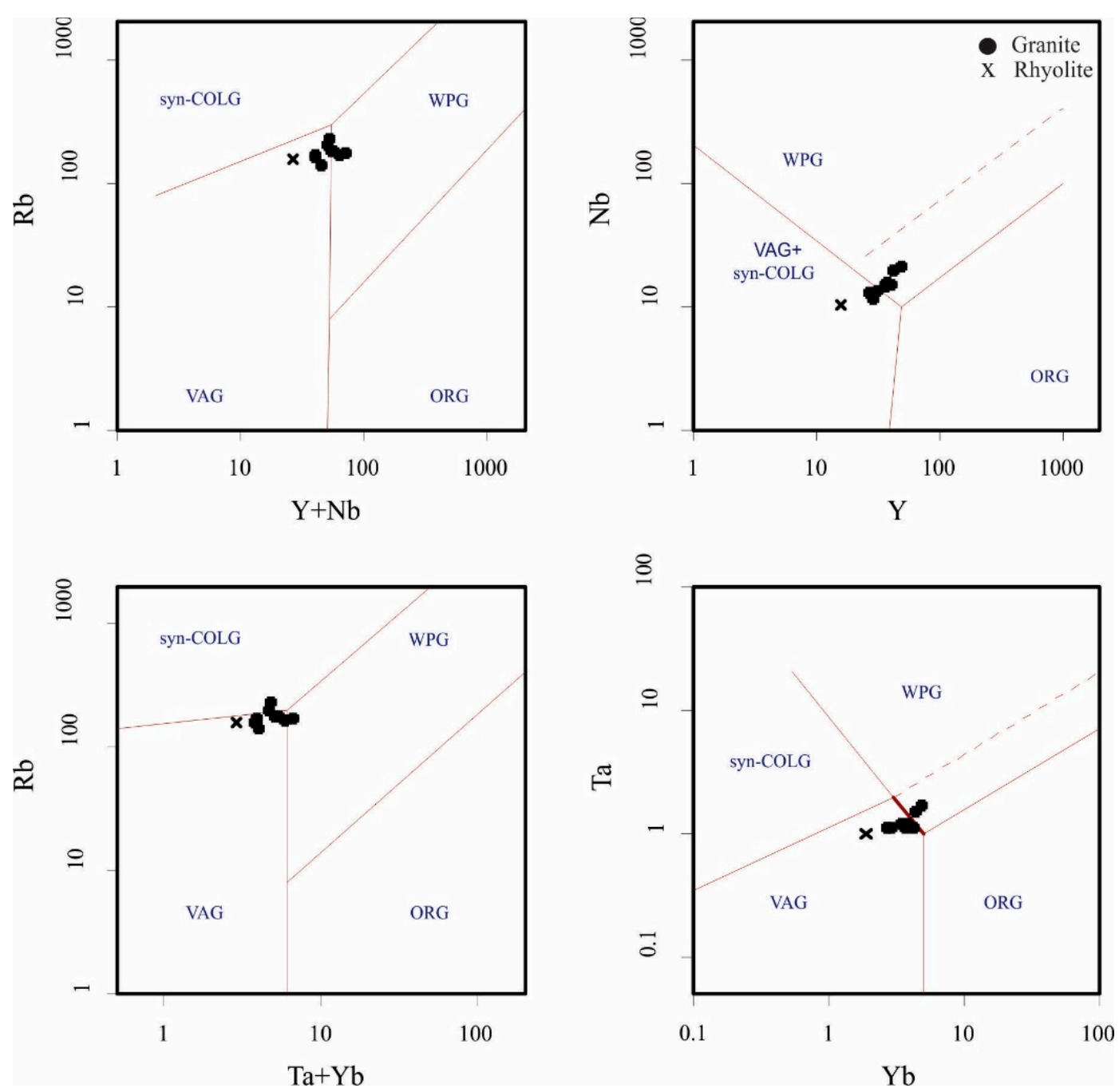

Figure 6. Tectonic discrimination diagram of unaltered samples of granite $(\bullet)$ and the rhyolitic dike (X). Post-COLG = post collisional; ORG = mid-oceanic ridge; syn-COLG = syn-collisional; VAG = volcanic arcs; WPG = within-plate [42]. 
Table 1. Chemical analysis of major and traces elements of the most representative rocks of the Tocantinzinho deposit.

\begin{tabular}{|c|c|c|c|c|c|c|c|c|c|c|c|c|c|c|c|c|c|c|}
\hline \multirow{2}{*}{$\begin{array}{c}\text { Lithology } \\
\text { Samples }\end{array}$} & \multicolumn{9}{|c|}{ Granite } & \multicolumn{2}{|c|}{ Rhyolite Basalt } & \multicolumn{3}{|c|}{ Microclinized Granite } & \multicolumn{4}{|c|}{ Phyllic Altered Granite } \\
\hline & $1 \_24$ & $37 \_24$ & $10 \_48 B$ & 4_48A & $4 \_48 B$ & $4 \_57$ & $23 \_24$ & $25 \_24$ & $27 \_24$ & 11_24 & $2 \_57$ & $10 \_48 \mathrm{~A}$ & $9 \_48$ & $54 \_24$ & $18 \_24$ & $19 \_48$ & $7 \_27$ & $55 \_24$ \\
\hline \multicolumn{19}{|l|}{ (\% weight) } \\
\hline $\mathrm{SiO}_{2}$ & 72.09 & 72.89 & 72.5 & 70.97 & 71.17 & 72.38 & 72.05 & 71.8 & 71.62 & 73.47 & 42.43 & 74.85 & 75.49 & 59.84 & 71.81 & 55.66 & 77.51 & 64.02 \\
\hline $\mathrm{Al}_{2} \mathrm{O}_{3}$ & 14.04 & 13.24 & 11.33 & 13.67 & 14.02 & 12.97 & 14 & 13.42 & 14.23 & 10.98 & 11.66 & 12.32 & 11.62 & 15.57 & 13.3 & 15.69 & 11.91 & 16.06 \\
\hline $\mathrm{TiO}_{2}$ & 0.27 & 0.26 & 0.26 & 0.48 & 0.47 & 0.23 & 0.33 & 0.32 & 0.32 & 0.11 & 0.51 & 0.27 & 0.25 & 0.58 & 0.35 & 1.09 & 0.22 & 0.45 \\
\hline $\mathrm{Fe}_{2} \mathrm{O}_{3}$ & 1.73 & 2.3 & 3.47 & 3.43 & 2.56 & 2.44 & 1.96 & 1.81 & 2.4 & 1.99 & 9.19 & 1.66 & 1.42 & 4.81 & 1.75 & 6.15 & 0.79 & 3.59 \\
\hline $\mathrm{MnO}$ & 0.04 & 0.03 & 0.05 & 0.04 & 0.03 & 0.03 & 0.03 & 0.06 & 0.02 & 0.17 & 0.5 & 0.02 & 0.04 & 0.12 & 0.05 & 0.16 & 0.03 & 0.07 \\
\hline $\mathrm{MgO}$ & 0.31 & 0.53 & 0.36 & 1.34 & 1.25 & 0.44 & 0.35 & 0.4 & 0.54 & 0.48 & 7.46 & 0.22 & 0.27 & 1.62 & 0.34 & 5.53 & 0.48 & 1.23 \\
\hline $\mathrm{CaO}$ & 0.92 & 0.49 & 1.51 & 0.54 & 0.52 & 0.8 & 0.64 & 1.46 & 0.39 & 1.95 & 12.06 & 0.77 & 1.15 & 4.38 & 3.55 & 3.47 & 0.16 & 2.93 \\
\hline $\mathrm{Na}_{2} \mathrm{O}$ & 3.87 & 3.46 & 2.92 & 2.72 & 2.96 & 3.1 & 3.43 & 3.23 & 2.57 & 2.47 & 0.02 & 3.27 & 3.05 & 4.95 & 3.55 & 5.47 & 3.62 & 4.57 \\
\hline $\mathrm{K}_{2} \mathrm{O}$ & 5.33 & 5.01 & 4.49 & 4.65 & 4.88 & 5.3 & 5.4 & 5.17 & 5.89 & 5.35 & 1.72 & 4.98 & 4.93 & 3.09 & 5.15 & 0.98 & 4.38 & 3.96 \\
\hline $\mathrm{P}_{2} \mathrm{O}_{5}$ & 0.03 & 0.08 & 0.05 & 0.12 & 0.13 & 0.06 & 0.1 & 0.08 & 0.06 & 0.05 & 0.22 & 0.07 & 0.05 & 0.25 & 0.1 & 0.34 & 0.05 & 0.19 \\
\hline LOI & 1.2 & 1.4 & 2.8 & 1.7 & 1.7 & 2 & 1.5 & 2 & 1.7 & 2.8 & 13.8 & 1.4 & 1.5 & 4.4 & 2 & 5.2 & 0.7 & 2.6 \\
\hline Total & 99.83 & 99.69 & 99.74 & 99.66 & 99.69 & 99.75 & 99.79 & 99.75 & 99.74 & 99.82 & 99.57 & 99.83 & 99.77 & 99.61 & 101.95 & 99.74 & 99.85 & 99.67 \\
\hline \multicolumn{19}{|l|}{ (ppm) } \\
\hline $\mathrm{Ba}$ & 600 & 741 & 421 & 622 & 637 & 565 & 678 & 638 & 712 & 248 & 216 & 502 & 476 & 1106 & 703 & 144 & 337 & 1298 \\
\hline $\mathrm{Sr}$ & 111.8 & 108.5 & 94.1 & 117.5 & 123.4 & 92.1 & 131.9 & 158.4 & 98.3 & 90.9 & 602.2 & 93.9 & 91.4 & 638 & 141 & 130.1 & 66.1 & 714.5 \\
\hline $\mathrm{Rb}$ & 199.9 & 160 & 139.9 & 1667.4 & 171.2 & 169.9 & 179.1 & 181.1 & 227.9 & 156.7 & 142 & 147.7 & 150.5 & 124 & 166.9 & 20.9 & 131.4 & 122.8 \\
\hline $\mathrm{Zr}$ & 226.4 & 209.4 & 189.2 & 230.6 & 289.4 & 144.5 & 268.5 & 232.4 & 233.8 & 78.2 & 94.9 & 181.4 & 185.6 & 156.4 & 256.4 & 226.7 & 143.1 & 178.4 \\
\hline Y & 36.2 & 26.6 & 31.3 & 42.2 & 49.3 & 29 & 38.3 & 40.9 & 36.6 & 15.7 & 16.8 & 35.9 & 34.1 & 13.7 & 34.4 & 18.3 & 14.4 & 13.6 \\
\hline $\mathrm{Nb}$ & 14.3 & 12.7 & 13.5 & 19.6 & 21.4 & 11.3 & 15.3 & 15.2 & 15.2 & 10.4 & 6.4 & 13.2 & 12.5 & 8.5 & 15.8 & 21.2 & 9.3 & 11.9 \\
\hline $\mathrm{Ga}$ & 15.7 & 14.4 & 11.9 & 18.9 & 17.7 & 14.7 & 15.7 & 15.3 & 18.1 & 12 & 24.1 & 12.6 & 12.3 & 17 & 15 & 20.1 & 12.7 & 18.7 \\
\hline Th & 21.8 & 13.6 & 16.7 & 14.8 & 22.8 & 10.5 & 13.2 & 16.9 & 14.8 & 20.8 & 3.4 & 18.3 & 18.2 & 6.5 & 17.7 & 8.1 & 20.9 & 9.8 \\
\hline W & 178.4 & 123.2 & 202.6 & 108.7 & 94.1 & 251.7 & 126.2 & 123.9 & 68.2 & 231.4 & 28 & 130 & 220.3 & 67.2 & 86.6 & 90 & 99.4 & 105.2 \\
\hline Cs & 1.8 & 1.7 & 1.5 & 2.4 & 2.6 & 2.1 & 2.8 & 2.3 & 3.2 & 1.4 & 3.8 & 1.7 & 1.6 & 2 & 2.4 & 0.2 & 1.1 & 1.9 \\
\hline $\mathrm{Hf}$ & 6.4 & 5.8 & 6.1 & 7.5 & 9.6 & 4.7 & 8.1 & 7 & 7.1 & 3.2 & 2.4 & 5.9 & 5.6 & 4.5 & 7.5 & 5.8 & 5.3 & 5 \\
\hline $\mathrm{Ta}$ & 1.2 & 1.1 & 1.1 & 1.5 & 1.7 & 1.1 & 1.2 & 1.1 & 1.1 & 1 & 0.3 & 1 & 1 & 0.6 & 1.3 & 0.7 & 0.6 & 0.9 \\
\hline $\mathrm{U}$ & 3 & 2.9 & 3.2 & 4.2 & 6.6 & 3.1 & 2.7 & 4.3 & 3.3 & 4.9 & 1.2 & 3.7 & 4.5 & 2.2 & 3.4 & 1.9 & 2.5 & 3.8 \\
\hline $\mathrm{V}$ & 9 & 12 & 10 & 41 & 34 & 21 & 14 & 14 & 18 & $<8$ & 113 & 10 & 11 & 74 & 12 & 66 & 12 & 43 \\
\hline $\mathrm{Ag}$ & $<0.1$ & 3.4 & 1.6 & 1.1 & 0.3 & 1.2 & 0.4 & 0.1 & 0.3 & 1.1 & $<0.1$ & 0.4 & $<0.1$ & $<0.1$ & 8.5 & 0.2 & $<0.1$ & 0.2 \\
\hline As & 0.8 & 10.3 & 3.8 & 6 & 3.8 & 8.9 & 13.4 & 7.8 & 13.2 & 3.2 & 2 & 6 & 2.7 & 1 & 5.6 & 0.7 & $<0.5$ & 0.7 \\
\hline $\mathrm{Bi}$ & $<0.1$ & 2.5 & 0.4 & 0.8 & 0.4 & 1.3 & 0.3 & 0.3 & 0.2 & 0.4 & 0.1 & 0.8 & 0.7 & $<0.1$ & 1.1 & 22.7 & 1.3 & 0.3 \\
\hline $\mathrm{Cd}$ & $<0.1$ & 0.6 & $<0.1$ & $<0.1$ & $<0.1$ & $<0.1$ & $<0.1$ & $<0.1$ & $<0.1$ & $<0.1$ & 0.2 & $<0.1$ & $<0.1$ & $<0.1$ & 11.3 & $<0.1$ & $<0.1$ & $<0.1$ \\
\hline $\mathrm{Cu}$ & 5 & 367 & 87.3 & 22.9 & 12.5 & 18.4 & 6.7 & 11.2 & 11.2 & 10.6 & 1.7 & 57.1 & 25.1 & 6.1 & 812.5 & 30.4 & 1.9 & 23.8 \\
\hline $\mathrm{Hg}$ & 0.01 & 0.05 & 0.06 & 0.03 & 0.06 & 0.09 & 0.04 & 0.04 & 0.03 & 0.1 & $<0.01$ & 0.03 & 0.08 & 0.01 & 0.03 & 0.01 & 0.04 & $<0.01$ \\
\hline Mo & 1.1 & 3 & 0.9 & 3 & 0.9 & 1.3 & 0.8 & 1.2 & 0.3 & 3.6 & 0.7 & 3 & 1.7 & 3.6 & 2.2 & 0.2 & 0.1 & 0.7 \\
\hline $\mathrm{Ni}$ & 6.8 & 1.6 & 1.4 & 29.3 & 13.6 & 6.9 & 1 & 3.5 & 8.5 & 2.9 & 75.1 & 1.4 & 2 & 5.9 & 8.5 & 17.8 & 0.6 & 6.9 \\
\hline $\mathrm{Pb}$ & 8.3 & 142.6 & 11.6 & 95.6 & 274.7 & 67.7 & 22.7 & 35 & 20.8 & 43.4 & 13.3 & 16 & 6.5 & 6.8 & 450.6 & 3.7 & 1.5 & 30.9 \\
\hline
\end{tabular}


Table 1. Cont

\begin{tabular}{|c|c|c|c|c|c|c|c|c|c|c|c|c|c|c|c|c|c|c|}
\hline \multirow{2}{*}{$\begin{array}{c}\text { Lithology } \\
\text { (ppm) }\end{array}$} & \multicolumn{9}{|c|}{ Granite } & \multicolumn{2}{|c|}{ Rhyolite Basalt } & \multicolumn{3}{|c|}{ Microclinized Granite } & \multicolumn{4}{|c|}{ Phyllic Altered Granite } \\
\hline & & & & & & & & & & & & & & & & & & \\
\hline $\mathrm{Sb}$ & $<0.1$ & $<0.1$ & $<0.1$ & $<0.1$ & $<0.1$ & $<0.1$ & $<0.1$ & $<0.1$ & $<0.1$ & $<0.1$ & $<0.1$ & $<0.1$ & $<0.1$ & $<0.1$ & $<0.1$ & $<0.1$ & $<0.1$ & $<0.1$ \\
\hline Se & $<0.5$ & 0.8 & 0.5 & $<0.5$ & $<0.5$ & 0.6 & 0.9 & $<0.5$ & 0.9 & $<0.5$ & $<0.5$ & $<0.5$ & $<0.5$ & $<0.5$ & 0.5 & $<0.5$ & $<0.5$ & $<0.5$ \\
\hline $\mathrm{Tl}$ & $<0.1$ & $<0.1$ & 0.1 & $<0.1$ & $<0.1$ & $<0.1$ & $<0.1$ & $<0.1$ & 0.1 & $<0.1$ & $<0.1$ & $<0.1$ & $<0.1$ & $<0.1$ & $<0.1$ & $<0.1$ & $<0.1$ & $<0.1$ \\
\hline $\mathrm{Zn}$ & 25 & 102 & 24 & 15 & 24 & 21 & 24 & 26 & 22 & 21 & 155 & 15 & 18 & 75 & 844 & 196 & 22 & 54 \\
\hline $\mathrm{La}$ & 52.8 & 45.6 & 42.3 & 53.8 & 65.1 & 42.3 & 56 & 57.4 & 60.5 & 30.7 & 15.8 & 39.4 & 40.8 & 32.2 & 52.9 & 45 & 16 & 36.3 \\
\hline $\mathrm{Ce}$ & 120.3 & 107.4 & 97.5 & 121.1 & 145.8 & 93 & 131.8 & 133.1 & 136.8 & 60.2 & 38.8 & 93.5 & 95 & 72 & 121.9 & 100.6 & 54 & 77.4 \\
\hline $\operatorname{Pr}$ & 12.5 & 11.88 & 11.12 & 14.44 & 17.4 & 11.27 & 14.75 & 14.72 & 14.79 & 6.13 & 4.33 & 10.86 & 11.11 & 7.71 & 13.75 & 11.62 & 3.95 & 7.9 \\
\hline $\mathrm{Nd}$ & 45.7 & 43.7 & 40.5 & 55.1 & 66.1 & 41.5 & 54.4 & 54.2 & 56.1 & 6.13 & 17.7 & 41.1 & 40.3 & 28.8 & 52.5 & 45.2 & 14.2 & 28.1 \\
\hline Sm & 8.3 & 7.81 & 7.21 & 9.8 & 11.18 & 7.15 & 9.88 & 25_24 & 9.81 & 3.21 & 3.66 & 7.56 & 7.28 & 4.85 & 8.78 & 7.55 & 2.83 & 4.53 \\
\hline $\mathrm{Eu}$ & 0.98 & 0.89 & 0.81 & 1.14 & 1.26 & 0.81 & 1.09 & 71.8 & 1.14 & 0.49 & 1.13 & 0.79 & 0.76 & 1.19 & 1.08 & 1.05 & 0.49 & 0.99 \\
\hline $\mathrm{Gd}$ & 6.82 & 6.21 & 6.08 & 7.75 & 8.96 & 5.46 & 8.11 & 13.42 & 7.85 & 2.79 & 3.41 & 6.53 & 6.11 & 3.73 & 7.41 & 5.01 & 2.42 & 3.46 \\
\hline $\mathrm{Tb}$ & 1.15 & 0.95 & 1.02 & 1.28 & 1.46 & 0.91 & 1.28 & 0.32 & 1.25 & 0.44 & 0.56 & 1.14 & 1 & 0.6 & 1.14 & 0.61 & 0.38 & 0.45 \\
\hline Dy & 6.81 & 4.9 & 5.65 & 6.88 & 7.69 & 4.77 & 7.16 & 1.81 & 6.93 & 2.52 & 3.16 & 6.43 & 5.6 & 2.73 & 6.53 & 3.17 & 1.97 & 1.9 \\
\hline Ho & 1.28 & 1.03 & 1.12 & 1.46 & 1.7 & 1.02 & 1.44 & 0.06 & 1.39 & 0.54 & 0.58 & 1.3 & 1.17 & 0.53 & 1.3 & 0.59 & 0.41 & 0.48 \\
\hline Er & 3.63 & 2.98 & 3.24 & 4.32 & 4.92 & 2.88 & 4.1 & 0.4 & 3.98 & 1.7 & 1.76 & 3.72 & 3.4 & 1.45 & 3.84 & 1.84 & 1.12 & 1.5 \\
\hline $\mathrm{Tm}$ & 0.58 & 0.46 & 0.49 & 0.68 & 0.76 & 0.44 & 0.65 & 1.46 & 0.61 & 0.28 & 0.26 & 0.57 & 0.54 & 0.22 & 0.58 & 0.34 & 0.18 & 0.25 \\
\hline $\mathrm{Yb}$ & 3.47 & 2.7 & 2.93 & 4.4 & 4.86 & 2.72 & 3.87 & 3.23 & 3.69 & 1.9 & 1.76 & 3.28 & 1 & 1.43 & 3.47 & 2.36 & 1.26 & 1.69 \\
\hline $\begin{array}{c}\mathrm{Lu} \\
(\mathrm{ppb})\end{array}$ & 0.46 & 0.39 & 0.42 & 0.62 & 0.72 & 0.38 & 0.55 & 5.17 & 0.52 & 0.32 & 0.25 & 0.46 & 0.47 & 0.23 & 0.52 & 0.42 & 0.19 & 0.28 \\
\hline $\mathrm{Au}$ & 3.3 & $13,033.7$ & 4774.8 & 2061.3 & 306.5 & 2722.2 & 771.8 & 0.08 & 474.1 & 3239.1 & 4282 & 489.9 & 86.9 & 4.1 & 38,133 & 18.7 & $<0.5$ & 19.9 \\
\hline
\end{tabular}




\subsection{Hydrothermal Alteration and Mineralization}

The Tocantinzinho gold deposit is host to the monzogranite strongly affected by hydrothermal alteration. In the study area, the two main varieties of altered and mineralized rocks are usually classified by the natives as Salame and Smoky (Figure 9), but these names have also been used in the literature about the region $[8,21-23,48]$. The rocks assigned as Salame are thus named because of their red color, which is due to the intense red color of K-feldspar crystals. The Smoky samples are rich in chlorite and sericite, which gives them a grayish coloration. In this research, the hydrothermal rocks are referred to according to their predominant hydrothermal alteration.

The following main types of hydrothermal alteration were identified in the studied rocks: microclinization, silicification, chloritization, sericitization and carbonatization.



Figure 7. Chondrite [42] normalized REE plots for the unaltered monzogranite, showing the pronounced negative anomaly of Eu and the similar patterns of the unaltered granite samples $(\bullet)$ [42].

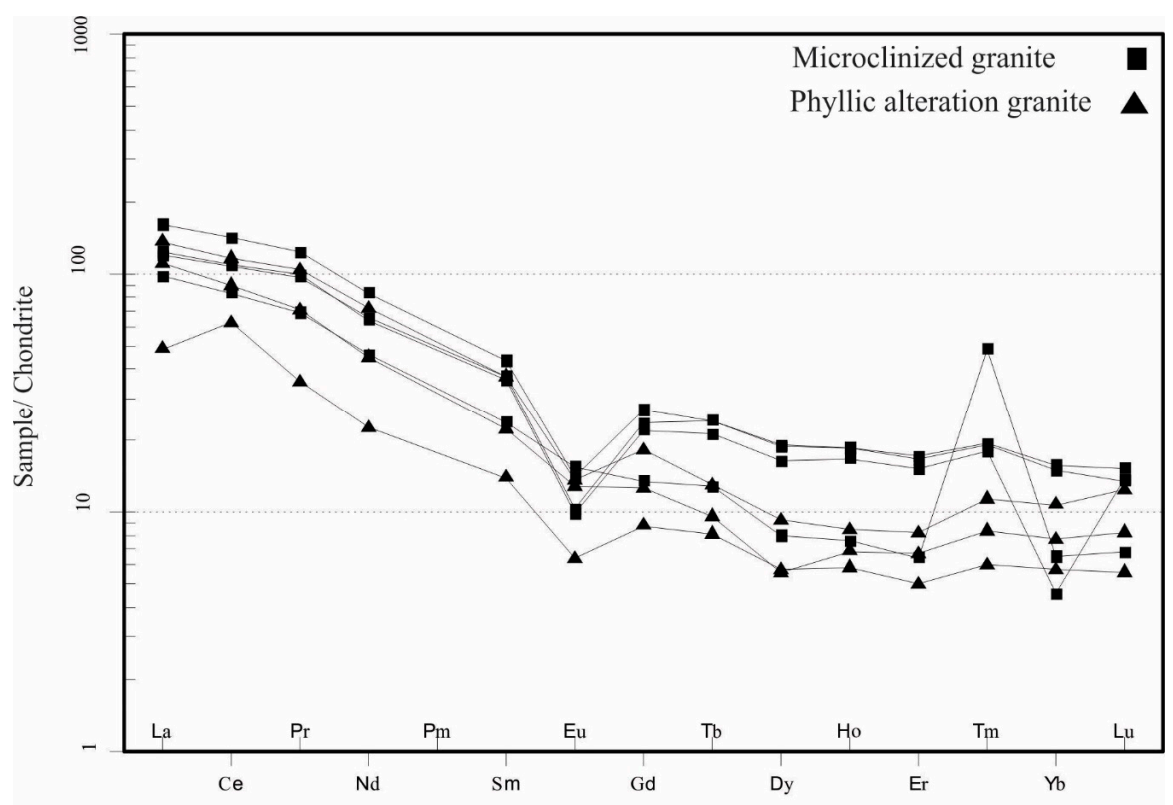

Figure 8. Chondrite [42] normalized REE plots for the altered monzogranites of the Tocantinzinho deposit: (ם) Microclinized granite samples; ( $\mathbf{\Delta})$ Phyllic-altered samples. 
During the early stage of hydrothermal alteration, incipient metasomatism modified the primary mineralogy of the granite rock. The orthoclase was microclinized, the oligoclase crystals were altered to albite and the magmatic biotite is rarely preserved and was altered to green chlorite (Chl1). There is neoformation of quartz, referred to as quartz grain 1 (Qtz1) and quartz grain 2 (Qtz2), which occur in altered rocks as a result of incipient and advanced silicification, respectively (Table 2).

During the microclinization stage, a strong alteration of K-feldspar occurred and formed microcline masses surrounding previously-formed minerals. The hydrothermal quartz grains are disseminated and acquired a milky aspect. The second stage of chloritization occurred, forming brown chlorite (Chl2), with an increase in the amount of sulfides (pyrite and chalcopyrite). Rutile is a sub-product of the chloritization of biotite, commonly found along chlorite cleavages.

The term "phyllic alteration" is used to designate the main sericitization stage, accompanied by the association of sericite, pyrite and Qtz2 (plus gold \pm chlorite). Mineralization occurs predominantly during this stage. The amount and variety of sulfides (pyrite, chalcopyrite, sphalerite, galena and altaite) increased, which occur in paragenesis with the gold mineralization. The last alteration stage is characterized by chloritization (Chl3) and carbonatization (Figure 10).

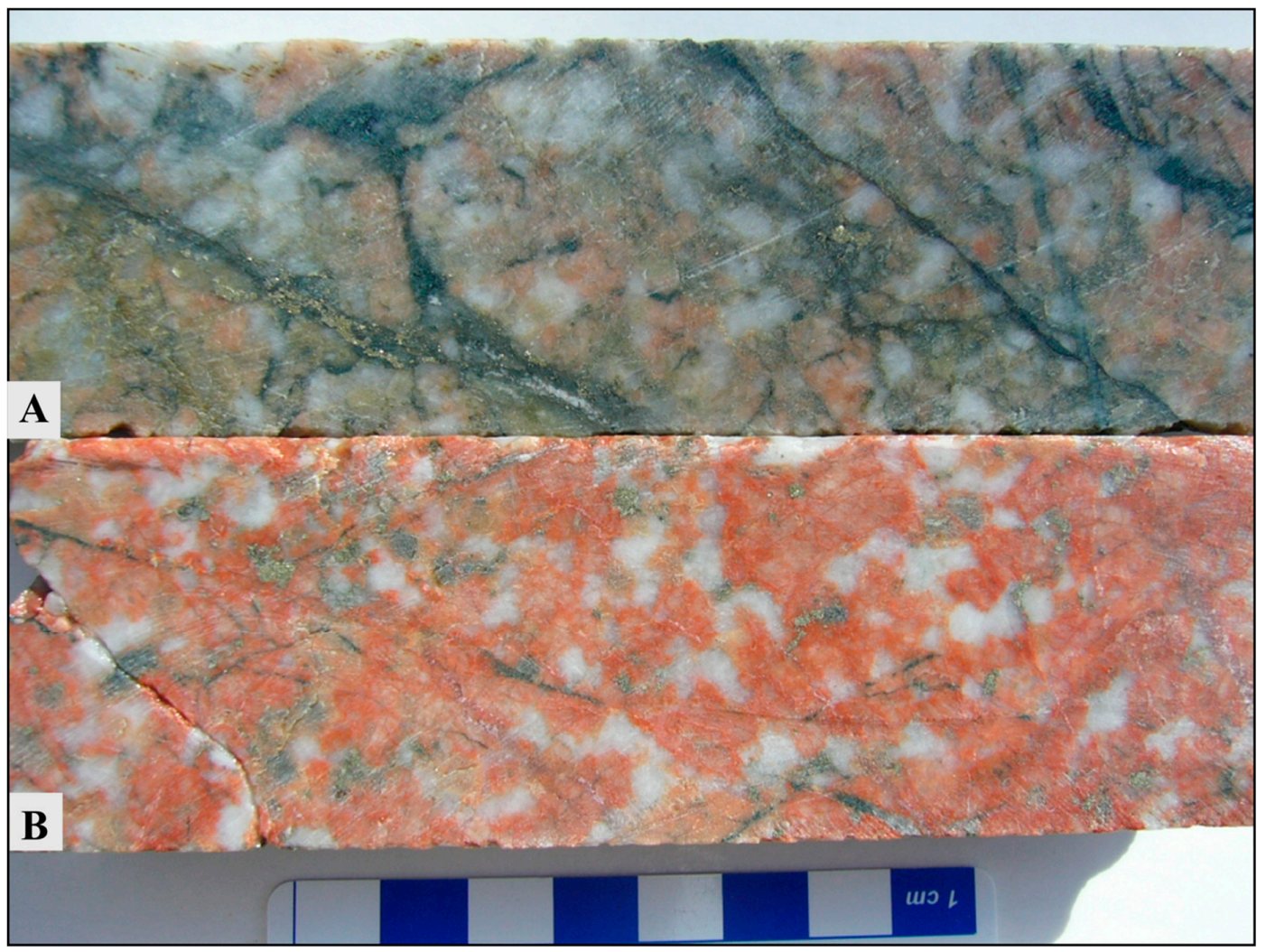

Figure 9. (A) Phyllic-altered granite (Smoky); (B) Microclinized granite (Salame) showing the association between potassium feldspar crystals and milky quartz grains.

The silicification occurs in two main stages: the first, incipient, occurs soon after the magmatic stage, where the first hydrothermal quartz grains (Qtz1) were formed; the second occurs during the phyllic alteration stage (Qtz2), forming large quantities of mono- and poly-ore veinlets. The most common mineralizing paragenesis in this case is: K-feldspar + Qtz1 + pyrite + gold (microclinization phase) and Qtz2 + sericite + pyrite + gold (phyllic alteration phase).

Chlorite occurs in three distinct stages. In weakly metasomatized rocks, chlorite is the result of the destabilization of biotite (Chl1) and is green and accompanied by titanite + epidote + muscovite \pm magnetite. In places where the alteration is more intense, chlorite (Chl2) is usually brownish and has an anomalous interference color, accompanied by sericite + sulfides \pm calcite, 
associated with the phyllic alteration stage. The other form (Chl3) occurs in masses, is brownish, isolated in late monomineralic veins and associated with the final stage of phyllic alteration.

Carbonatization occurs less intensely than the other types of alteration. It probably occurs in the final phases of the hydrothermal alteration process along with chloritization (Chl3). In general, potassic feldspar and albite are affected by carbonatization. Calcite was identified as carbonate in microprobe analyses. The hydrothermal alteration and mineralization stages are inextricably linked. We observed that, in certain phases of alteration, there is a greater presence of ore in the paragenesis; these phases are the phyllic alteration, accompanied or not by silicification and microclinization. Figure 11 contains the interpreted paragenetic sequence of the studied rocks.
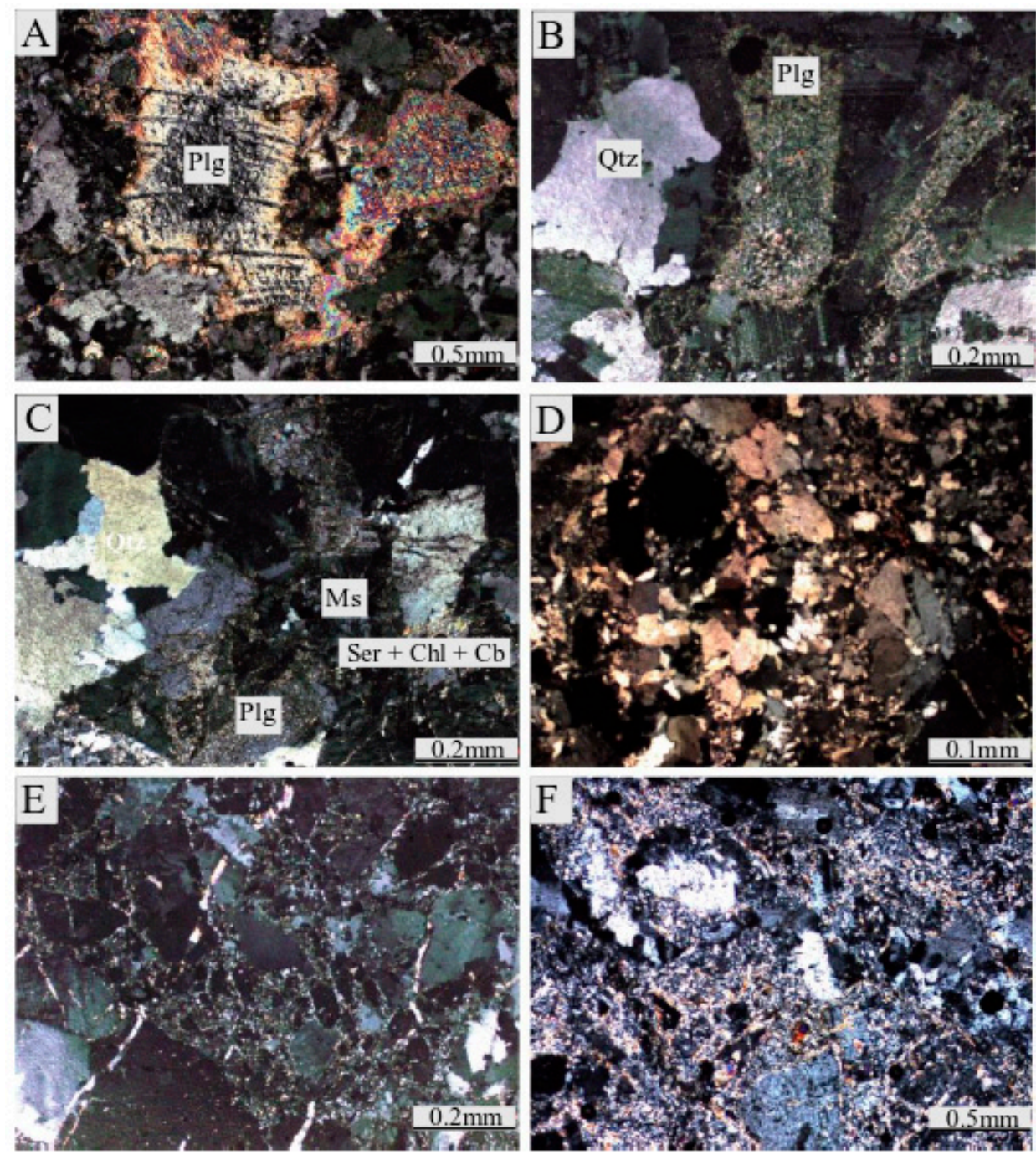

Figure 10. Photomicrography of hydrothermalized samples with crossed nicols. (A) Plagioclase crystals altered to carbonate. (B) Sericitized plagioclase in paragenesis with quartz1. (C) Hypidiomorphic texture with muscovite and sericitized plagioclase crystals, and chlorite and carbonate veins. (D) Clusters or mass of recrystallized quartz and plagioclase crystals, in paragenesis with pyrite crystals. (E) Cluster/mass of plagioclase crystals and quartz associated with sulfides. (F) Intense sericitization in paragenesis with sulfide (pyrite + chalcopyrite + magnetite) and zircon. Plg: plagioclase; Qtz: quartz; Ms: muscovite; Ser: sericite; $\mathrm{Chl}$ : chlorite; $\mathrm{Cb}$ : carbonate. 


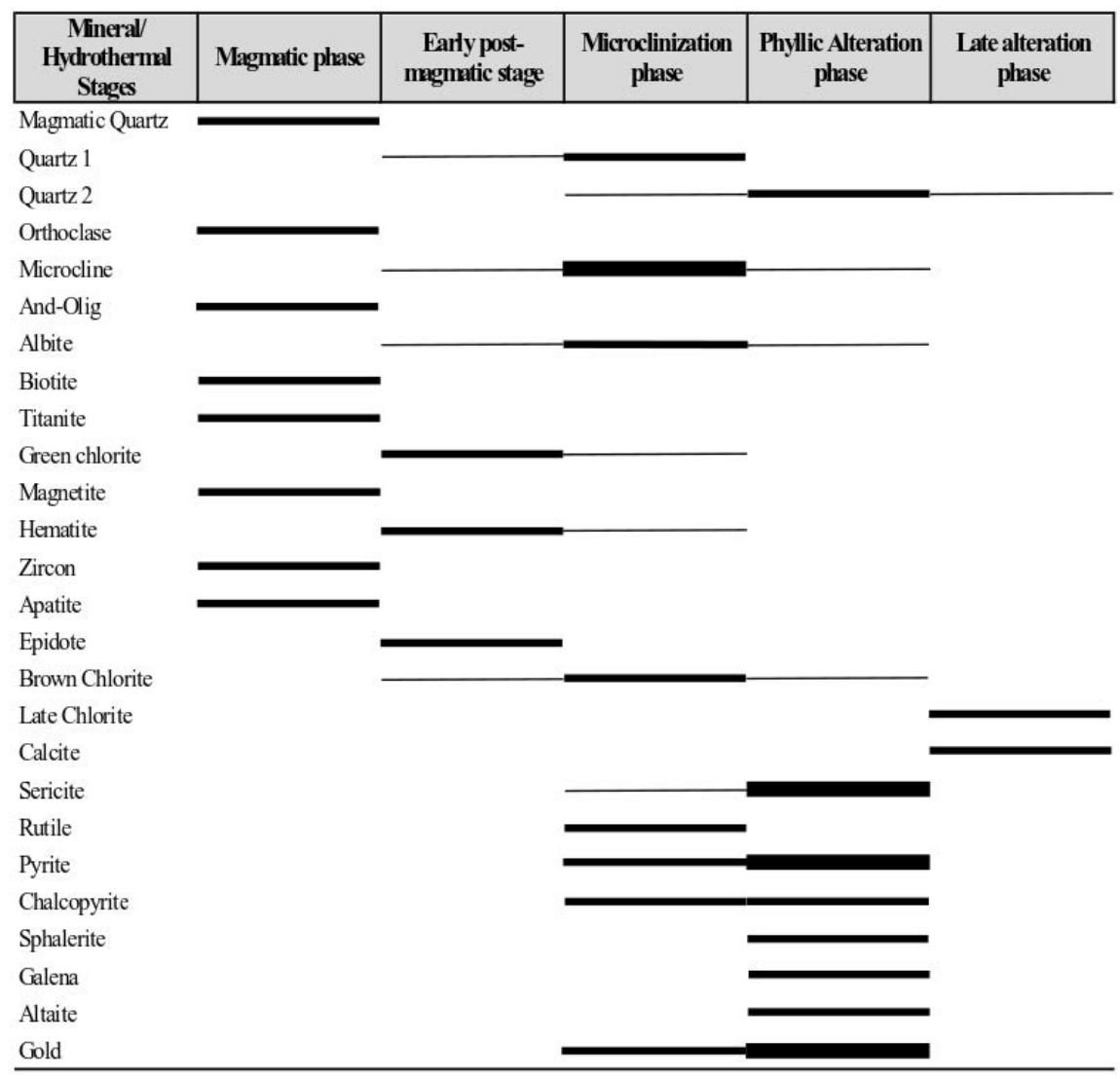

Figure 11. Paragenetic sequence of mineralization and hydrothermal alteration of Tocantinzinho deposit.

\subsection{Mineralogy and Chemistry of Chlorite}

The chemical data of the three types of chlorite are summarized in Table 2 and the formulas, based on 28 atoms of oxygen, are as follows: Chl1: $\left(\mathrm{Mg}_{4.84} \mathrm{Fe}_{4.44} \mathrm{Mn}_{0.19} \mathrm{Ti}_{0.04} \mathrm{Al}_{2.30}\right)_{11,81}\left(\mathrm{Si}_{5.67} \mathrm{Al}_{2.33}\right)_{8}$ $\mathrm{O}_{20}(\mathrm{OH})_{16}, \mathrm{Chl} 2:\left(\mathrm{Mg}_{4.59} \mathrm{Fe}_{4.75} \mathrm{Mn}_{0.19} \mathrm{Al}_{2.36}\right)_{11.92}\left(\mathrm{Si}_{5.44} \mathrm{Al}_{2.56}\right)_{8} \mathrm{O}_{20}\left(\mathrm{OH}_{0.98} \mathrm{Cl}_{0.02}\right)_{16}$ and Chl3: $\left(\mathrm{Mg}_{4.12}\right.$ $\left.\mathrm{Fe}_{4.56} \mathrm{Mn}_{0.16} \mathrm{Ti}_{0.02} \mathrm{Al}_{2.37}\right)_{11.23}\left(\mathrm{Si}_{5.53} \mathrm{Al}_{2.47}\right)_{8} \mathrm{O}_{20}\left(\mathrm{OH}_{0.99} \mathrm{Cl}_{0.01}\right)_{16}$.

The chlorite compositions are clinochlore (Ch11 and Chl3), with $\mathrm{Fe} /(\mathrm{Fe}+\mathrm{Mg})\left(\mathrm{X}_{\mathrm{Fe}}\right)=0.43$, which occur in the least altered samples and chamosite $\left(\mathrm{Chl} 2 ; \mathrm{X}_{\mathrm{Fe}}=0.60\right)$, present in the more altered and mineralized rocks, with $\mathrm{Al}^{\mathrm{IV}}$ ranging from 2.03 to 2.76. The petrographic and compositional differences between the chlorite types suggest that $\mathrm{Chl} 2$ chlorite occurs in paragenesis with microclinization, which is the first mineralization stage (Figure 12) and with phyllic alteration.

The estimated crystallization temperature of the chamosite (Chl2), calculated according to Cathelineau [25] showed variation from 302 to $382{ }^{\circ} \mathrm{C}$, whereas the calculated crystallization temperature of clinochlore (Chl1 and Chl3) ranges from 266 to $340{ }^{\circ} \mathrm{C}$, regardless of its generation. These temperature estimates are useful and coherent for comparison to the fluid inclusion data. Although it is empirical and considering the conclusions of De Caritat et al. [49], chlorite geothermometry should be used with caution and only in combination with alternative methods of estimating paleotemperatures. The chlorite geothermomether was used together with fluid inclusion data to estimate the temperature of the hydrothermal system in the Tapajos deposit. 



Figure 12. Photomicrography of the analyzed chlorite samples. (A) Type 1 chlorite (Chl1), resulting from biotite alteration. (B) Chl2, in paragenesis with sulfides (pyrite and sphalerite) and silica, (C) previous photo with x-nicols. (D) Chl3 forming monomineralic masses/veins. Sp: sphalerite;

Chl: chlorite; Py: pyrite; Ser: sericite; Qtz: quartz; Plg: plagioclase.

\subsection{Mineralogy of Gold and Associated Minerals}

The goal of the petrographic study of mineralized samples was to improve our understanding of the relationship between gold mineralization and monzogranite, in addition to trying to understand the genesis, transport and precipitation of the ore. Petrographic and chemical data obtained by electron microprobe analyses were integrated with other data in an attempt to propose a genetic model for the deposit. The main sulfides associated with the ore were analyzed in order to better understand the main characteristics of the mineralization.

Pyrite is anhedral to subhedral and varies in size between 100 and $200 \mu \mathrm{m}$. When it occurs in paragenesis with sericite, it is rich in other sulfide inclusions (chalcopyrite, sphalerite, galena and altaite). Chalcopyrite varies in size from 50 to $100 \mu \mathrm{m}$. It occurs as inclusions in pyrite or intergrown with galena, sphalerite and rutile. $\mathrm{Pb}$ and Te sulfides (galena and altaite) are also included in pyrite (Table 3). Sphalerite, galena and altaite are included in pyrite or aggregates. Normally, gold is included or in fractures (Figure 13).

Gold occurs, generally and in greater proportion, in association with pyrite and quartz from the second generation of hydrothermal quartz (Qtz2) in the phyllic alteration stage but is also observed in the microclinization stage, where the first hydrothermal quartz grains (Qtz1) were formed (Figure 11).

There are three kinds of ore representation in the Tocantinzinho deposit: free gold, gold included in other minerals and gold in pyrite fractures. Free gold is richer in $\mathrm{Au}(91 \% \mathrm{Au}$ and $9 \% \mathrm{Ag})$. As inclusions, it behaves differently in pyrite and sphalerite (Table 4). In the first case, its composition is richer in $\mathrm{Au}$ (89\% on average) and relatively equivalent in $\mathrm{Ag}(11 \%)$. Gold included in sphalerite has $78 \% \mathrm{Au}$ in its composition. Gold in fractures is richer when in sphalerite crystals $(90 \% \mathrm{Au}$ and $10 \%$ $\mathrm{Ag}$ ), whereas pyrite fractures are poorer in $\mathrm{Au}(72 \%)$ (Figure 14). 


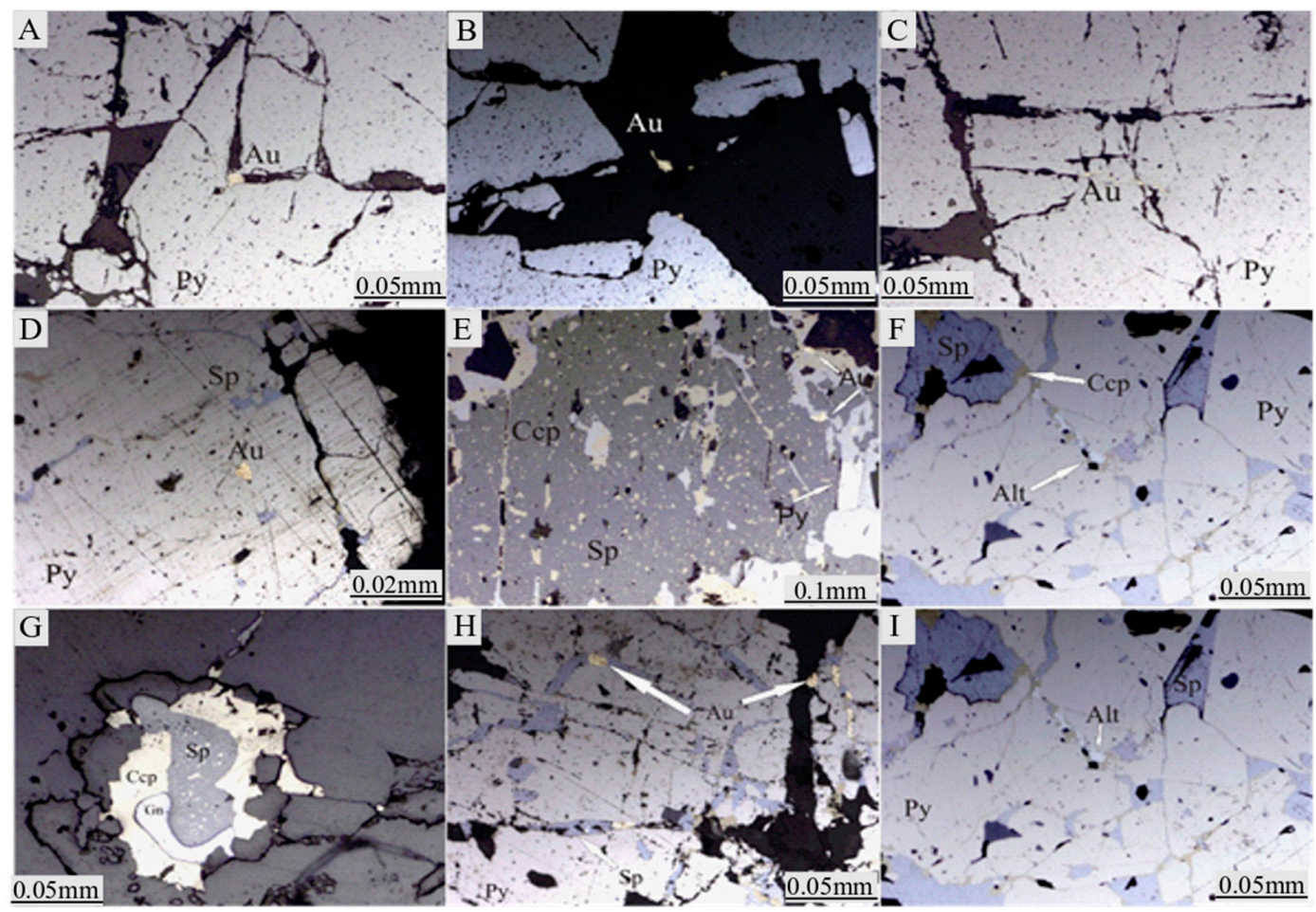

Figure 13. Photomicrographs of sulfide and mineralized samples of the Tocantinzinho deposit. (A-C) Paragenesis of $\mathrm{Py}+\mathrm{Au}$, highlighting the pyrite crystal having little or no inclusion of sulfides. In $(\mathrm{A}-\mathrm{C})$, the $\mathrm{Au}$ is included in fractures and in B it is free, in a Qtz crystal. (D-F) Py in paragenesis with other sulfides; in (D), the Py exhibits intergrowth/substitution for sphalerite, also Ccp and Alt filling Py fractures. (G) Sphalerite grains (Sp), chalcopyrite (Ccp) and galena (Gn) (sample 18_24). (H) Association of pyrite (Py), Sp and gold (Au) (sample S18_24); (I) paragenesis sample of Py, Sp and Alt (lead telluride (TePb)) (sample S18_24). Au: gold; Py: pyrite; Sp: Sphalerite; Ccp: chalcopyrite; Gn: galena; Alt: altaite. 
Table 2. Chemical results obtained from electron microprobe of the chlorite types in samples from different lithotypes.

\begin{tabular}{|c|c|c|c|c|c|c|c|c|c|c|c|c|c|c|c|c|c|}
\hline Sample & $\begin{array}{c}1 \_24 \\
\text { (1) }\end{array}$ & $\begin{array}{c}54 \_24 \\
\text { (3) }\end{array}$ & $\begin{array}{c}54 \_24 \\
\text { (5) }\end{array}$ & $\begin{array}{c}54 \_24 \\
\text { (5) }\end{array}$ & $\begin{array}{c}54 \_24 \\
(2-3)\end{array}$ & $\begin{array}{c}54 \_24 \\
\text { (6) }\end{array}$ & $\begin{array}{c}1 \_24 \\
(7)\end{array}$ & $\begin{array}{c}\text { 2_57 } \\
\text { (1) }\end{array}$ & $\begin{array}{l}2 \_57 \\
(1-1)\end{array}$ & $\begin{array}{l}2-57 \\
(1-2)\end{array}$ & $\begin{array}{c}4 \_8 \mathrm{~A} \\
\text { (2) }\end{array}$ & $\begin{array}{c}1 \_24 \\
\text { (3) }\end{array}$ & $\begin{array}{c}\text { 2_57 } \\
\text { (3) }\end{array}$ & $\begin{array}{c}\text { 4_48A } \\
\text { (3) }\end{array}$ & $\begin{array}{c}448 \mathrm{~A} \\
\text { (3) }\end{array}$ & $\begin{array}{c}\text { 4_48A } \\
(4-3)\end{array}$ & $\begin{array}{c}4 \_48 \mathrm{~A} \\
(4-4)\end{array}$ \\
\hline $\mathrm{SiO}_{2}$ & 27.011 & 27.352 & 27.19 & 27.19 & 27.352 & 25.48 & 27.222 & 25.165 & 26.121 & 25.616 & 25.108 & 26.919 & 26.112 & 26.416 & 26.416 & 23.351 & 25.542 \\
\hline $\mathrm{Al}_{2} \mathrm{O}_{3}$ & 18.716 & 18.744 & 18.373 & 18.373 & 18.744 & 19.61 & 19.253 & 19.647 & 20.531 & 19.52 & 20.333 & 18.656 & 19.785 & 21.777 & 21.777 & 18.701 & 20.483 \\
\hline $\mathrm{FeO}$ & 23.271 & 24.696 & 24.634 & 24.634 & 24.696 & 27.973 & 21.761 & 23.244 & 23.69 & 25.1 & 31.515 & 22.465 & 23.738 & 30.536 & 30.536 & 30.733 & 29.922 \\
\hline $\mathrm{MnO}$ & 1.404 & 0.371 & 0.387 & 0.387 & 0.371 & 0.408 & 1.44 & 0.41 & 0.44 & 0.407 & 0.419 & 1.471 & 0.402 & 0.467 & 0.467 & 0.463 & 0.405 \\
\hline $\mathrm{BaO}$ & 0 & 0.017 & 0 & 0 & 0.017 & 0.08 & 0 & 0 & 0 & 0 & 0.026 & 0.016 & 0.021 & 0 & 0 & 0.098 & 0.009 \\
\hline $\mathrm{Na}_{2} \mathrm{O}$ & 0.051 & 0 & 0.004 & 0.004 & 0 & 0.025 & 0.024 & 0.007 & 0 & 0.008 & 0 & 0.03 & 0 & 0 & 0 & 0.045 & 0.024 \\
\hline $\mathrm{K}_{2} \mathrm{O}$ & 0.002 & 0 & 0.049 & 0.049 & 0 & 0 & 0 & 0.008 & 0.041 & 0 & 0.022 & 0.007 & 0.002 & 0.017 & 0.017 & 0.05 & 0.001 \\
\hline $\mathrm{Cl}$ & 0.013 & 0.028 & 0.025 & 0.025 & 0.028 & 0.01 & 0 & 0.02 & 0 & 0.008 & 0 & 0 & 0 & 0 & 0 & 0 & 0.012 \\
\hline F & 0.285 & 0.254 & 0.36 & 0.36 & 0.254 & 0.001 & 0.181 & 0.057 & 0.082 & 0.228 & 0 & 0.186 & 0.073 & 0.001 & 0.001 & 0.028 & 0.103 \\
\hline Site $\mathrm{T}$ & 8 & 8 & 8 & 8 & 8 & 8 & 8 & 8 & 8 & 8 & 8 & 8 & 8 & 8.027 & 8 & 8 & 8 \\
\hline $\mathrm{Al}^{\mathrm{VI}}$ & 2.321 & 2.339 & 2.175 & 2.175 & 2.339 & 2.431 & 2.673 & 2.468 & 2.535 & 2.334 & 2.698 & 2.415 & 2.410 & 2.981 & 2.981 & 2.371 & 2.718 \\
\hline $\mathrm{Fe}$ & 3.227 & 3.404 & 3.387 & 3.387 & 0.458 & 3.421 & 3.064 & 3.310 & 3.262 & 3.515 & 4.514 & 3.151 & 3.288 & 4.231 & 4.231 & 4.616 & 4.247 \\
\hline $\mathrm{Mg}$ & 4.088 & 3.934 & 4.060 & 4.060 & 0.529 & 4.010 & 3.781 & 4.101 & 4.058 & 4.064 & 2.640 & 4.062 & 4.204 & 2.568 & 2.568 & 2.958 & 2.852 \\
\hline Mn & 0.026 & 0.007 & 0.007 & 0.007 & 0.007 & 0.008 & 0.029 & 0.008 & 0.008 & 0.008 & 0.008 & 0.028 & 0.008 & 0.009 & 0.010 & 0.009 & 0.081 \\
\hline Ti & 0.002 & 0.055 & 0.010 & 0.010 & 0.006 & 0 & 0.001 & 0.002 & 0.002 & 0 & 0.001 & 0 & 0.002 & 0 & 0 & 0 & 0.009 \\
\hline $\mathrm{Ca}$ & 0.010 & 0.0542 & 0.088 & 0.088 & 0.054 & 0.025 & 0.033 & 0.004 & 0.006 & 0.006 & 0 & 0.011 & 0.006 & 0.004 & 0.004 & 0.014 & 0.007 \\
\hline $\mathrm{Na}$ & 0.021 & 0 & 0.002 & 0.002 & 0 & 0.010 & 0.010 & 0.003 & 0 & 0.003 & 0 & 0.012 & 0 & 0 & 0 & 0.011 & 0.010 \\
\hline K & 0.0005 & 0 & 0.013 & 0.013 & 0 & 0 & 0 & 0.002 & 0.011 & 0 & 0.006 & 0.002 & 0 & 0.005 & 0.005 & 0.015 & 0 \\
\hline Site $\mathrm{O}$ & 9.695 & 9.794 & 9.742 & 9.742 & 3.394 & 9.904 & 9.592 & $\begin{array}{l}9.898 \\
\end{array}$ & 9.883 & 9.929 & 9.868 & 9.682 & 9.918 & 9.799 & 9.799 & 10.003 & 9.926 \\
\hline
\end{tabular}


Table 3. Representative results of electron microprobe analysis from sphalerite, pyrite, galena and altaite.

\begin{tabular}{ccccccccccccc}
\hline Pyrite & $\mathbf{A s}$ & $\mathbf{S}$ & $\mathbf{B i}$ & $\mathbf{A g}$ & $\mathbf{T e}$ & $\mathbf{P b}$ & $\mathbf{A u}$ & $\mathbf{F e}$ & $\mathbf{C u}$ & $\mathbf{Z n}$ & $\mathbf{N i}$ & Total \\
\hline 8-57_C2 & 0 & 52.92 & 0.208 & 0 & 0.043 & 0.15 & 0.056 & 46.59 & 0 & 0 & 0 & 99.967 \\
8-57_C1 & 0 & 53.107 & 0.123 & 0.024 & 0 & 0.109 & 0.052 & 46.611 & 0.084 & 0 & 0.001 & 100.111 \\
8-57_C3 & 0 & 53.73 & 0.141 & 0.018 & 0.036 & 0.103 & 0.089 & 47.371 & 0 & 0.094 & 0 & 101.582 \\
18-24 & 0 & 53.354 & 0.086 & 0 & 0.051 & 0.073 & 0 & 46.798 & 0.258 & 0 & 0 & 100.62 \\
\hline Sphalerite & $\mathbf{A s}$ & $\mathbf{S}$ & $\mathbf{B i}$ & $\mathbf{A g}$ & $\mathbf{T e}$ & $\mathbf{P b}$ & $\mathbf{A u}$ & $\mathbf{F e}$ & $\mathbf{C u}$ & $\mathbf{Z n}$ & $\mathbf{N i}$ & Total \\
\hline 18-24 & 0 & 33.584 & 0.156 & 0.012 & 0.023 & 0.068 & 0.033 & 7.367 & 8.576 & 49.426 & 0.090 & 99.335 \\
18-24 & 0.01 & 33.259 & 0.051 & 0 & 0.001 & 0 & 0 & 0.74 & 0.583 & 64.563 & 0 & 99.207 \\
18-24 & 0.017 & 33.004 & 0.130 & 0.008 & 0.030 & 0 & 0 & 0.874 & 0.444 & 64.344 & 0.038 & 98.889 \\
S18-24 & 0 & 32.820 & 0.096 & 0 & 0.03 & 0 & 0 & 0.131 & 0 & 64.816 & 0.032 & 97.925 \\
\hline Galena & $\mathbf{A s}$ & $\mathbf{S}$ & $\mathbf{B i}$ & $\mathbf{A g}$ & $\mathbf{T e}$ & $\mathbf{P b}$ & $\mathbf{A u}$ & $\mathbf{F e}$ & $\mathbf{C u}$ & $\mathbf{Z n}$ & $\mathbf{N i}$ & Total \\
\hline 18-24 & 0 & 13.386 & 0.327 & 0 & 0.051 & 85.417 & 0 & 0.037 & 0.024 & 0.063 & 0.147 & 99.452 \\
18-24 & 0 & 13.401 & 0.366 & 0 & 0.091 & 85.345 & 0 & 0.039 & 0.109 & 0.11 & 0.108 & 99.569 \\
18-24 & 0 & 13.278 & 0.352 & 0 & 0.11 & 85.065 & 0 & 0.048 & 0.035 & 0 & 0.019 & 98.907 \\
S18-24 & 0 & 13.341 & 0.376 & 0.033 & 0 & 84.135 & 0 & 0 & 0.116 & 0 & 0 & 98.001 \\
S18-24 & 0 & 13.402 & 0.465 & 0.04 & 0.03 & 84.290 & 0 & 0.015 & 0 & 0 & 0.032 & 98.274 \\
S18-24 & 0 & 13.433 & 0.265 & 0 & 0.065 & 85.344 & 0 & 0.014 & 0 & 0 & 0 & 99.121 \\
S18-24 & 0 & 13.388 & 0.347 & 0 & 0.046 & 83.532 & 0 & 1.184 & 0 & 0 & 0.055 & 98.552 \\
S18-24 & 0 & 13.473 & 0.36 & 0 & 0.034 & 84.426 & 0 & 0.934 & 0 & 0 & 0.116 & 99.343 \\
S18-24 & 0 & 13.439 & 0.437 & 0 & 0.044 & 84.126 & 0 & 0.02 & 0 & 0.606 & 0.04 & 98.712 \\
\hline Altaite (PbTe) & $\mathbf{A s}$ & $\mathbf{S}$ & $\mathbf{B i}$ & $\mathbf{A g}$ & $\mathbf{T e}$ & $\mathbf{P b}$ & $\mathbf{A u}$ & $\mathbf{F e}$ & $\mathbf{C u}$ & $\mathbf{Z n}$ & $\mathbf{N i}$ & Total \\
\hline S18-24 & 0 & 0.072 & 0.578 & 0.07 & 37.101 & 58.711 & 0 & 0.975 & 0.242 & 0 & 0.046 & 97.795 \\
\hline
\end{tabular}




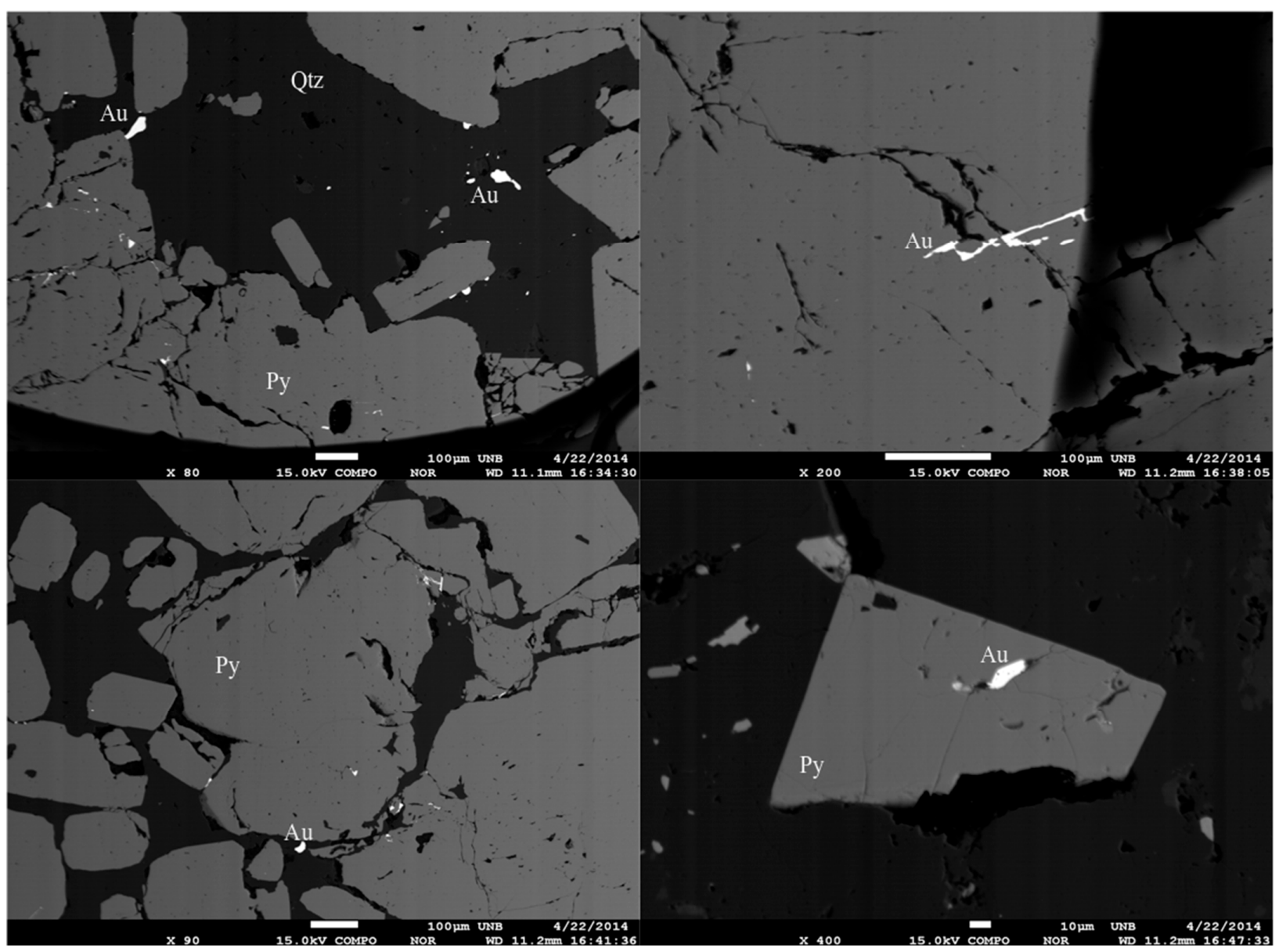

Figure 14. Images of backscattered electrons from the electron microprobe analysis showing the main occurrences of native gold in the Tocantinzinho deposit: (A) free gold in a mass of silicification in pyrite (sample S18_24); (B) Gold in a pyrite fracture (sample 8_57); (C) included gold, filling pyrite fractures (sample 8_57); (D) gold included in pyrite. Qtz: quartz; Py: pyrite; Au: gold. 
Table 4. Representative data of electron microprobe analyses of gold from the Tocantinzinho deposit.

\begin{tabular}{|c|c|c|c|c|c|c|c|c|c|c|c|c|c|c|c|c|c|}
\hline \multicolumn{4}{|c|}{ Au Free } & \multicolumn{8}{|c|}{ Au Includes } & \multicolumn{6}{|c|}{ Au Fractures } \\
\hline & Qtz & Qtz & Qtz & Py & Py & Py & Py & $\mathrm{Sp}$ & $\mathrm{Sp}$ & $S p$ & $\mathrm{Sp}$ & Py & Py & $\mathrm{Sp}$ & $\mathrm{Sp}$ & $S p$ & $\mathrm{Sp}$ \\
\hline $\begin{array}{c}\text { Samples } \\
\text { No. }\end{array}$ & $\begin{array}{c}\text { 8- } \\
\text { 57_C3_Au } 5\end{array}$ & $\begin{array}{c}\text { 8- } \\
\text { 57_C2_Au } 1\end{array}$ & $\begin{array}{c}\text { 8- } \\
\text { 57_C2_Au } 2\end{array}$ & $\frac{\text { 8- }}{57 \_C 2 \_A u ~ 3}$ & $\begin{array}{c}\text { S18- } \\
\text { 24_Au } 6\end{array}$ & $\begin{array}{c}\text { S18- } \\
\text { 24_Au } 5\end{array}$ & $\begin{array}{c}\text { S18- } \\
\text { 24_Au } 12\end{array}$ & $\begin{array}{c}\text { S18- } \\
\text { 24_Au } 4\end{array}$ & $\begin{array}{c}\text { S18- } \\
\text { 24_Au } 9\end{array}$ & $\begin{array}{c}\text { S18- } \\
\text { 24_Au } 10\end{array}$ & $\begin{array}{c}\text { S18- } \\
\text { 24_Au } 11\end{array}$ & $\begin{array}{c}\text { 8- } \\
\text { 57_C3_Au } 6\end{array}$ & $\begin{array}{c}18- \\
\text { 24_Au } 1\end{array}$ & $\begin{array}{c}\text { S18- } \\
\text { 24_Au } 1\end{array}$ & $\begin{array}{c}\text { S18- } \\
\text { 24_Au } 2\end{array}$ & $\begin{array}{c}\text { S18- } \\
\text { 24_Au } 3\end{array}$ & $\begin{array}{c}\text { S18- } \\
\text { 24_Au } 8\end{array}$ \\
\hline As & 0 & 0 & 0 & 0 & 0 & 0 & 0 & 0 & 0.004 & 0 & 0.013 & 0 & 0.037 & 0.023 & 0 & 0.012 & 0.027 \\
\hline $\mathrm{s}$ & 0.115 & 0.06 & 0.086 & 0.137 & 0.032 & 0.06 & 0.064 & 0.033 & 0.063 & 12.116 & 0.05 & 20.238 & 4.079 & 0.027 & 0.005 & 0 & 0.056 \\
\hline $\mathrm{Bi}$ & 0.522 & 0.527 & 0.385 & 0.296 & 0.252 & 0.491 & 0.297 & 0.447 & 0.399 & 0.276 & 0.425 & 0.242 & 0.324 & 0.519 & 0.294 & 0.548 & 0.36 \\
\hline $\mathrm{Ag}$ & 8.359 & 9.665 & 8.337 & 8.633 & 11.249 & 10.678 & 11.499 & 9.151 & 12.743 & 7.184 & 11.961 & 5.128 & 8.999 & 8.501 & 6.548 & 11.134 & 12.316 \\
\hline $\mathrm{Te}$ & 0.051 & 0.014 & 0 & 0.077 & 0.063 & 0.019 & 0.032 & 0.061 & 0.045 & 0.147 & 0.052 & 0.002 & 0.029 & 0.072 & 0.018 & 0.001 & 0.041 \\
\hline $\mathrm{Pb}$ & 0 & 0 & 0 & 0 & 0 & 0 & 0 & 0 & 0 & 22.075 & 0 & 0 & 0 & 0 & 0 & 0 & 0.14 \\
\hline $\mathrm{Au}$ & 90.964 & 90.302 & 91.831 & 90.46 & 88.816 & 89.603 & 86.918 & 91.271 & 82.31 & 51.969 & 86.863 & 62.811 & 81.1 & 90.106 & 94.744 & 87.588 & 86.222 \\
\hline $\mathrm{Fe}$ & 0.519 & 0.068 & 0.079 & 0.212 & 0.729 & 0.539 & 0.253 & 0 & 0.69 & 9.019 & 0.003 & 16.094 & 4.688 & 0.04 & 0 & 0.014 & 0.734 \\
\hline $\mathrm{Cu}$ & 0 & 0.053 & 0 & 0 & 0 & 0 & 0 & 0.059 & 0 & 0.683 & 0 & 0 & 0 & 0 & 0.262 & 0 & 0 \\
\hline $\mathrm{Zn}$ & 0 & 0 & 0 & 0 & 0 & 0 & 0 & 0 & 0 & 0 & 0.392 & 0 & 0.06 & 0 & 0 & 0 & 0 \\
\hline $\mathrm{Ni}$ & 0.093 & 0 & 0 & 0.084 & 0 & 0.004 & 0 & 0.027 & 0 & 0.049 & 0 & 0.083 & 0.032 & 0.048 & 0 & 0 & 0.102 \\
\hline Total & 100.623 & 100.689 & 100.718 & 99.899 & 101.141 & 101.394 & 99.063 & 101.049 & 96.254 & 103.518 & 99.759 & 104.598 & 99.348 & 99.336 & 101.871 & 99.297 & 99.998 \\
\hline
\end{tabular}




\subsection{Fluid Inclusions}

\subsubsection{Petrography and Microthermometric Data}

Fluid inclusions were studied in quartz grains in paragenesis with microcline and albite (Qtz1), from the microclinization stage and the phyllic alteration stage (Qtz2). On the basis of the petrographic study, all of them were interpreted to be genetically related to the mineralizing fluid (Figure 15). The fluid inclusions were classified based on the Shepherd et al. [50] petrographic criteria and the thermometric data. The Eutectic temperature was not observed, but, according to the petrographic and microthermometric data, the system was modeled by the $\mathrm{H}_{2} \mathrm{O}-\mathrm{NaCl}$ system. The isolated and/or randomly distributed fluid inclusions in quartz grains were interpreted as primary fluid inclusions. The fluid inclusions aligned along fracture planes were considered secondary. We identified five different types of fluid inclusion in Qtz1 and Qtz2 quartz grains of the Tocantinzinho deposit (Figure 16A-F; Table 5).

Type I: Aqueous two-phase (Vapor $(\mathrm{V})+$ Liquid $(\mathrm{L})$ ) primary fluid inclusions that homogenize to vapor, oval and/or rounded in shape, dark, with size ranging from 8 to $16 \mu \mathrm{m}$, degree of fill $(\mathrm{F})=0.5-0.6$. They occur in Qtz2 grains associated with phyllic alteration. Ice melting temperature $\left(\mathrm{Tm}_{\text {(ice) }}\right)$ varies between -11.2 and $-2.5^{\circ} \mathrm{C}$, with mode from -4.7 to $-2.5^{\circ} \mathrm{C}$. Homogenization temperature $\left(\mathrm{Th}_{(\mathrm{t})}\right)$ varies from 304 to $433^{\circ} \mathrm{C}$. Eutectic temperature was not observed. The system was modeled by the $\mathrm{H}_{2} \mathrm{O}-\mathrm{NaCl}$ system, as is the common practice in the literature [50]. Salinity, calculated according to the $\mathrm{Tm}_{(\mathrm{ice})}$ for the $\mathrm{H}_{2} \mathrm{O}-\mathrm{NaCl}$ system, ranges from 4.2 to 15.1 in wt \% NaCl eq. and density values range from 0.43 to $0.76 \mathrm{~g} / \mathrm{cm}^{3}$, according to Bodnar $[26,27]$.

Type II: Aqueous two-phase $(\mathrm{L}+\mathrm{V})$ primary fluid inclusions that homogenize to liquid, ellipsoidal and rarely round in shape, dark, from 8 to $14 \mu \mathrm{m}$ and $\mathrm{F}=0.7-0.8$. They occur in the microclinization and phyllic alteration stages. $\mathrm{Tm}_{\text {(ice) }}$ ranges from -11.9 to $-1.2{ }^{\circ} \mathrm{C}$, with the mode at approximately $-5.5^{\circ} \mathrm{C}$. $\mathrm{Th}_{(\mathrm{t})}$ varies from 280 to $426^{\circ} \mathrm{C}$, with a mode of $350-400{ }^{\circ} \mathrm{C}$. Salinity was calculated to range from 2.1 to 15.9 wt \% NaCl eq. and density is between 0.49 and $0.90 \mathrm{~g} / \mathrm{cm}^{3}$.

Type III: Aqueous two-phase $(\mathrm{L}+\mathrm{V})$ primary fluid inclusions, oval to ellipsoidal, colorless to slightly brown, from 6 to $10 \mu \mathrm{m}$ and $\mathrm{F}=0.8-0.9$, which homogenize to liquid. They occur in Qtz1 and Qtz2, in the microclinization and phyllic alteration stages, respectively. As with Type I, Type III fluid inclusions are associated with the main stage of mineralization-the phyllic alteration stage (sericite + chlorite + pyrite + gold). $\mathrm{Tm}_{(\mathrm{ice})}$ occurs between -5.9 and $-1.5{ }^{\circ} \mathrm{C}$ and $\mathrm{Th}_{(\mathrm{t})}$ ranges from 203 to $370{ }^{\circ} \mathrm{C}$, with the mode between 300 and $350{ }^{\circ} \mathrm{C}$. Eutectic temperature was not observed. The system was modeled by the $\mathrm{H}_{2} \mathrm{O}-\mathrm{NaCl}$ system. Salinity and density were calculated to range from 1.22 to 8.27 wt \% $\mathrm{NaCl}$ eq. and from 0.61 to $0.94 \mathrm{~g} / \mathrm{cm}^{3}$, respectively.

Type IV: Aqueous two-phase $(\mathrm{L}+\mathrm{V})$ secondary fluid inclusions that occur in trails, oval and/or ellipsoidal in shape, colorless, from 3 to $10 \mu \mathrm{m}$ and $\mathrm{F}=0.85-0.95$, which homogenize to liquid. They occur in the two types of quartz that were studied and is the most abundant type of fluid inclusions. $\mathrm{Tm}_{\text {(ice) }}$ varies from -3.5 to $-0.1{ }^{\circ} \mathrm{C}$, with the mode at $-1.1^{\circ} \mathrm{C}$ and $\mathrm{Th}_{(\mathrm{t})}$ ranges from 100 to $291{ }^{\circ} \mathrm{C}$, with the mode between 150 and $200{ }^{\circ} \mathrm{C}$. Salinity in the range of 0.2 to $5.1 \mathrm{wt} \% \mathrm{NaCl}$ eq. and density from 0.72 to $0.96 \mathrm{~g} / \mathrm{cm}^{3}$ were calculated.

Type V: Monophase fluid inclusions, usually shapeless and dark, interpreted as aqueous vapor type (V), from 8 to $30 \mu \mathrm{m}$. They occur in the two types of quartz (Qtz1 and Qtz2). They did not present phase changes during the microthermometric tests, neither characteristics of leakage nor natural decrepitation. 

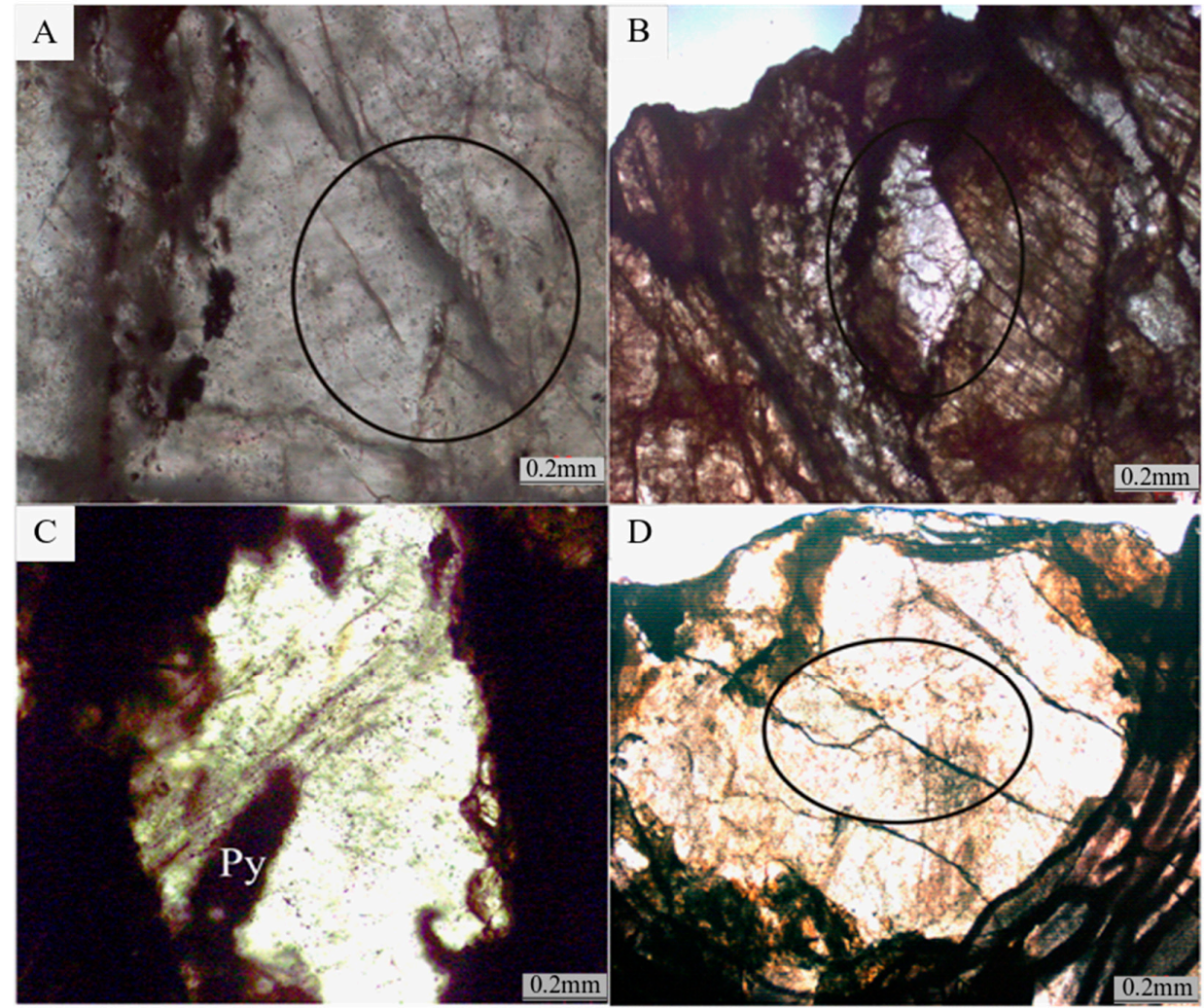

Figure 15. Photomicrographs of quartz samples selected for the fluid inclusions study. (A) Qtz1 showing the polygonal contacts in the grains. (B) Qtz2 strongly fractured and included by hydrothermally-altered material (sericite + chlorite). (C) Qtz2 surrounded by opaque minerals, such as pyrite (Py). (D) Qtz1: polygonal contours and weakly altered grain.

\subsubsection{Interpretation of the Fluid Inclusion Data}

Type I fluid inclusions present high values of $\mathrm{Th}_{(\mathrm{t})}$ and two predominant homogenization intervals (304-350 ${ }^{\circ} \mathrm{C}$ and $400-433^{\circ} \mathrm{C}$ ) (Figure 17A) and homogenize to vapor. Type II inclusions display the highest interval width for $\mathrm{Th}_{(\mathrm{t})}$, between 280 and $426^{\circ} \mathrm{C}$ (Figure 17B) and homogenize to liquid. Type III inclusions show $\mathrm{Th}_{(\mathrm{t})}$ values mode between 300 and $350{ }^{\circ} \mathrm{C}$ (Figure 17C). Type IV inclusions have the lowest $\mathrm{Th}_{(\mathrm{t})}$ values, with the mode ranging from 150 to $250^{\circ} \mathrm{C}$ (Figure 17D).

Type I and II fluid inclusions (Figure 18A,B, respectively) have higher salinity and $\mathrm{Th}_{(\mathrm{t})}$ values, whereas Type III is concentrated in the middle part of the $\mathrm{Th}_{(\mathrm{t})}$ vs. salinity diagram (Figure 18C). Type IV fluid inclusions (Figure 18D) have low salinity and $\mathrm{Th}_{(\mathrm{t})}$ values.

The $\mathrm{Th}_{(\mathrm{t})}$ vs. density (Figure 19) diagrams, obtained according to previously published equations $[26,27]$, demonstrate a negative correlation between density and $\mathrm{Th}_{(\mathrm{t})}$.

The difficulties in measuring Eutectic temperatures as described in this study are commonly reported in the literature, due to metastabilities or for fluid inclusions smaller than $10 \mu \mathrm{m}$ and with low salinities, especially smaller than $5 \mathrm{wt} \% \mathrm{NaCl}$ eq. [51], as was the situation of the fluid inclusions studied in this area. In this case, based on physicochemical studies for $\mathrm{H}_{2} \mathrm{O}$-salt solutions, the error in estimating salinities using the $\mathrm{H}_{2} \mathrm{O}-\mathrm{NaCl}$ system is considered to be $<5 \%$ [50].

Other studies that have been conducted in the same area, mostly in barren quartz veins, such as Queiroz [23] and Queiroz and Villas [48], reported the systems $\mathrm{H}_{2} \mathrm{O}-\mathrm{NaCl}-\mathrm{FeCl}_{2} \pm \mathrm{MgCl}_{2}$ and $\mathrm{H}_{2} \mathrm{O}-\mathrm{NaCl}-\mathrm{CaCl}_{2}$ in the Tocantinzinho deposit. 


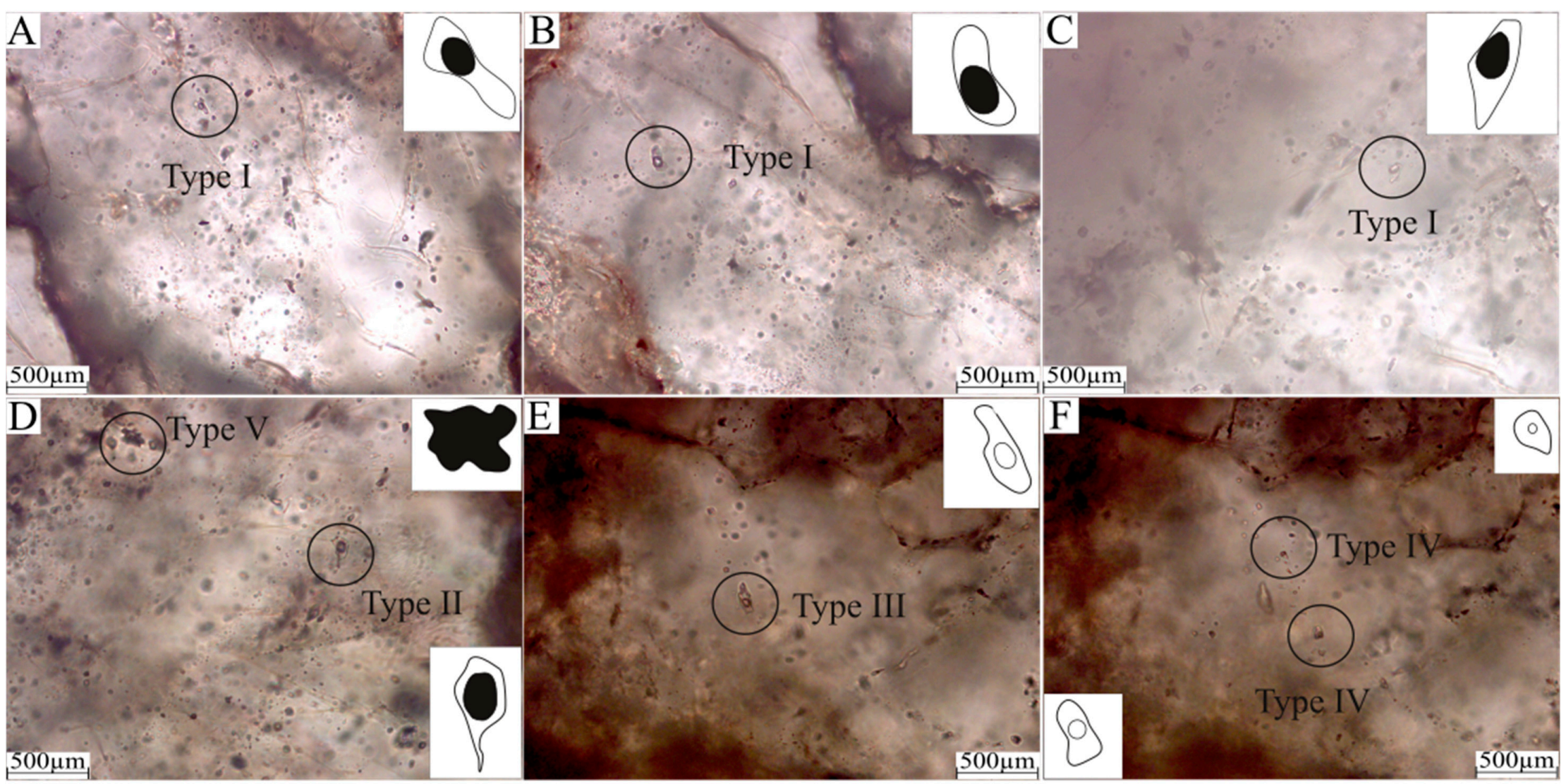

Figure 16. Photomicrographs showing the different types of fluid inclusions. (A-C) Type I. (D) Types II and V. (E) Type III. (F) Type IV. 
Table 5. Petrographic and microthermometric data of the fluid inclusions types from the Tocantinzinho deposit.

\begin{tabular}{|c|c|c|c|c|c|}
\hline Inclusion Type & Quartz Type/Occurrence & Hydrothermal Alteration & Petrographic Features & Microthermometric Data & System Model \\
\hline Type I & Qtz2 & Phyllic alteration. & $\begin{array}{l}\text { Primary inclusions of rare occurrence; } \\
\text { biphasic; round or oval; dark; } 8 \text { to } 16 \mu \mathrm{m} ; \\
\text { F = } 0.50 \text { to } 0.60 .\end{array}$ & $\begin{array}{c}\mathrm{Tm}_{\text {(ice) }} \text { of }-11.2^{\circ} \mathrm{C} \text { to }-2.5^{\circ} \mathrm{C} \text {, with a primary range } \\
\text { of }-4.7^{\circ} \mathrm{C} \text { to }-2.5^{\circ} \mathrm{C} ; \mathrm{Th}_{(\mathrm{t})} \text { of } 303.7^{\circ} \mathrm{C} \text { to } 432.6^{\circ} \mathrm{C} \text {; } \\
\text { salinity from } 4.18 \text { to } 15.17 \mathrm{wt} \% \mathrm{NaCl} \text { equiv., density } \\
\text { of } 0.43 \text { to } 0.84 \mathrm{~g} / \mathrm{cm}^{3} \text {. }\end{array}$ & $\mathrm{H}_{2} \mathrm{O}-\mathrm{NaCl}$ \\
\hline Type II & $\begin{array}{l}\text { Qtz1 } \\
\text { Qtz2 }\end{array}$ & $\begin{array}{l}\text { Phyllic alteration; } \\
\text { microclinization stage. }\end{array}$ & $\begin{array}{l}\text { Primary; biphasic; ellipsoidal and rounded; } \\
\text { dark; } 8 \text { to } 14 \mu \mathrm{m} ; \mathrm{F}=0.70 \text { to } 0.80 \text {. }\end{array}$ & $\begin{array}{l}\mathrm{Tm}_{\text {(ice) }} \text { from }-11.9^{\circ} \mathrm{C} \text { to }-1.2^{\circ} \mathrm{C} \text {, with primary } \\
\text { interval occurring between }-5.5^{\circ} \mathrm{C} \text { to }-1.2^{\circ} \mathrm{C} ; \mathrm{Th}_{(\mathrm{t})} \\
280.0 \text { to } 425.8^{\circ} \mathrm{C} \text {; salinity from } 3.54 \text { to } 20.14 \mathrm{wt}^{\circ} \% \\
\mathrm{NaCl} \text { eq.; density between } 0.32 \text { and } 0.90 \mathrm{~g} / \mathrm{cm}^{3} \text {. }\end{array}$ & $\mathrm{H}_{2} \mathrm{O}-\mathrm{NaCl}$ \\
\hline Type III & $\begin{array}{l}\text { Qtz1 } \\
\text { Qtz2 }\end{array}$ & $\begin{array}{l}\text { Microclinization stage; } \\
\text { phyllic alteration. }\end{array}$ & $\begin{array}{l}\text { Primary; biphasic; colorless; ellipsoidal and } \\
\text { rounded; ranges between } 6 \text { and } 10 \mu \mathrm{m} ; \\
\qquad \mathrm{F}=0.80 \text { to } 0.90 \text {. }\end{array}$ & $\begin{array}{c}\mathrm{Tm}_{\text {(ice) }} \text { of }-5.9^{\circ} \mathrm{C} \text { to }-1.5^{\circ} \mathrm{C} ; \mathrm{Th}_{(\mathrm{t})} \text { of } 203.2^{\circ} \mathrm{C} \text { to } \\
369.5^{\circ} \mathrm{C} \text {; salinity from } 1.22 \text { to } 8.27 \mathrm{wt} \% \mathrm{NaCl} \text { eq.; } \\
\text { density between } 0.61 \text { and } 0.94 \mathrm{~g} / \mathrm{cm}^{3} .\end{array}$ & $\mathrm{H}_{2} \mathrm{O}-\mathrm{NaCl}$ \\
\hline Type IV & $\begin{array}{l}\text { Qtz1 } \\
\text { Qtz2 }\end{array}$ & $\begin{array}{l}\text { Phyllic alteration; } \\
\text { microclinization stage. }\end{array}$ & $\begin{array}{l}\text { Secondary; biphasic; rounded the misshapen; } \\
\text { colorless; oscillate between } 3 \text { and } 10 \mu \mathrm{m} ; \\
\qquad \mathrm{F}=0.85 \text { to } 0.95 \text {. }\end{array}$ & $\begin{array}{c}\operatorname{Tm}_{\text {(ice) }}-3.5^{\circ} \mathrm{C} \text { to }-0.1^{\circ} \mathrm{C} \text {, while fashion presents } \\
\text { value of }-1.1^{\circ} \mathrm{C} ; \mathrm{Th}_{(\mathrm{t})} \text { of } 100.3^{\circ} \mathrm{C} \text { to } 290.9^{\circ} \mathrm{C} ; \\
\text { salinity between } 0.17 \text { and } 5.10 \mathrm{wt} \% \mathrm{NaCl} \text { eq.; } \\
\text { density between } 0.72 \text { and } 0.96 \mathrm{~g} / \mathrm{cm}^{3} \text {. }\end{array}$ & $\mathrm{H}_{2} \mathrm{O}-\mathrm{NaCl}$ \\
\hline Type V & $\begin{array}{l}\text { Qtz1 } \\
\text { Qtz2 }\end{array}$ & All assemblages. & $\begin{array}{l}\text { Dark; shapeless and rarely rounded; oscillate } \\
\text { between } 8 \text { to } 30 \mu \mathrm{m} .\end{array}$ & - & $\mathrm{H}_{2} \mathrm{O}-\mathrm{NaCl}$ \\
\hline
\end{tabular}


Comparing the described samples and the microthermometric data presented in those authors' reports, which contained analyses of fluid inclusion in samples of milky and massive quartz from veins and veinlets hosted in a hydrothermalized monzogranite, we observed that those fluids are not present in the main mineralized stages. The low homogenization temperatures described by those authors, for example, may suggest that the divalent cation-containing fluids probably represent secondary fluids. For this reason, they were considered in this paper as important additional data from the non-mineralizing fluids that also circulated through the Tocantinzinho deposit, probably in peripheral veins and veinlets.

For all five types of fluid inclusions described in this study, the petrographic and microthermometric interpretations show a complex situation regarding the fluids that circulated through the Tocantinzinho deposit. The presented data suggest the existence of aqueous fluids with low to moderate salinity and a great variety in $\mathrm{Th}_{(\mathrm{t})}$ and $\mathrm{Tm}_{\text {(ice) }}$. The coexistence in equilibrium, in the same quartz grain, of fluid inclusions that homogenize to different phases, as well as the presence of monophasic non-carbonic inclusions (Type V), is interpreted as the possible evidence of occurrence of boiling during magmatic fluid ascent, as defined by Shepherd et al. [50], and, lately, as a mixture of magmatic and meteoric fluids.

\section{Discussion}

The geological, petrographic and geochemical compositions of the Tocantinzinho monzogranite align with granite from a magmatic-arc tectonic setting (Figure 20). The geochemical composition of the rhyolitic dike that occurs, cutting monzogranite in the deposit, is similar to granite composition. They are interpreted as having a comagmatic origin.

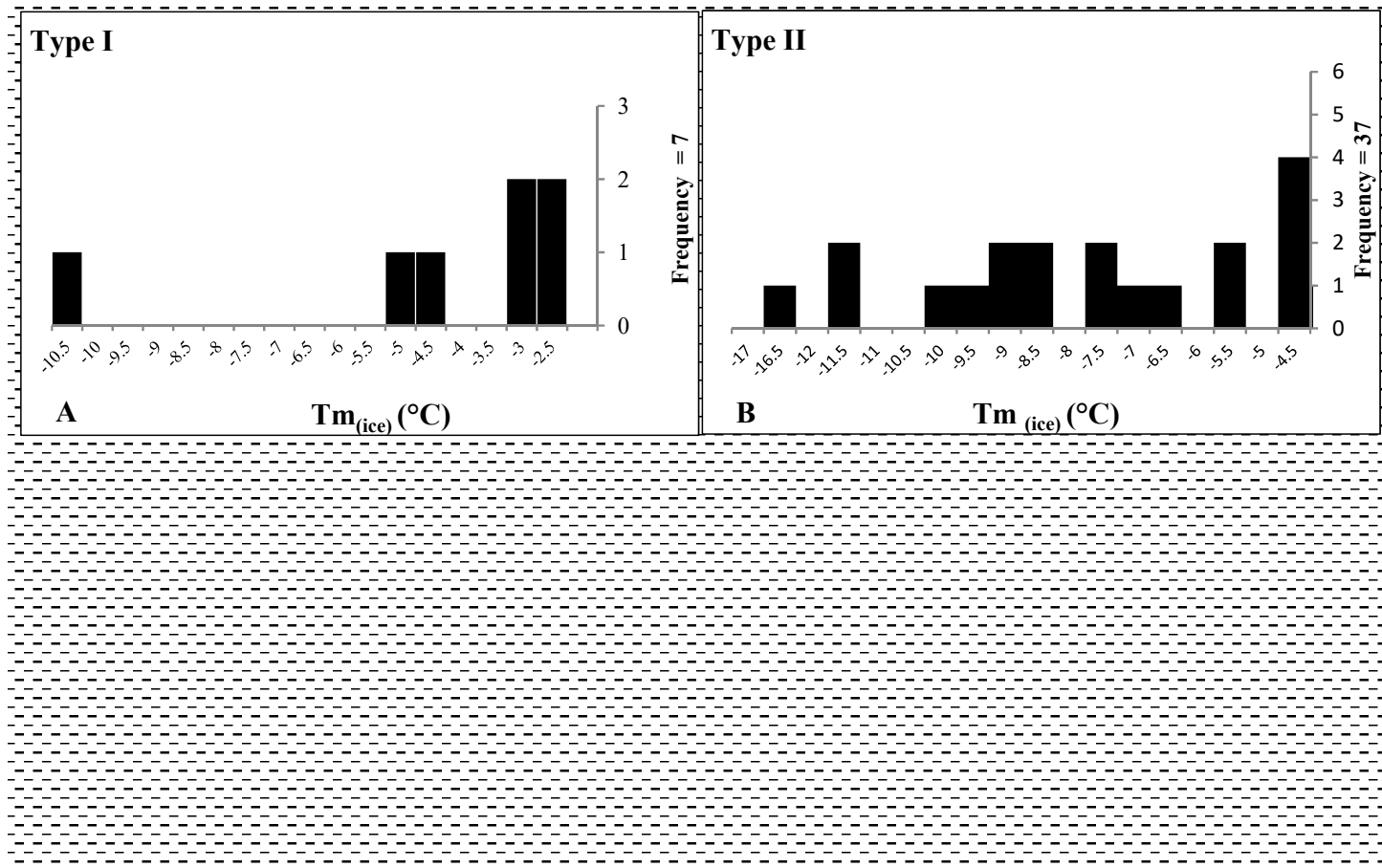

Figure 17. Histograms of melting ice temperature $\left(\mathrm{Tm}_{(\mathrm{ice})}\right)$ variation vs. frequency of the four main types of fluid inclusion in the Tocantinzinho deposit. 


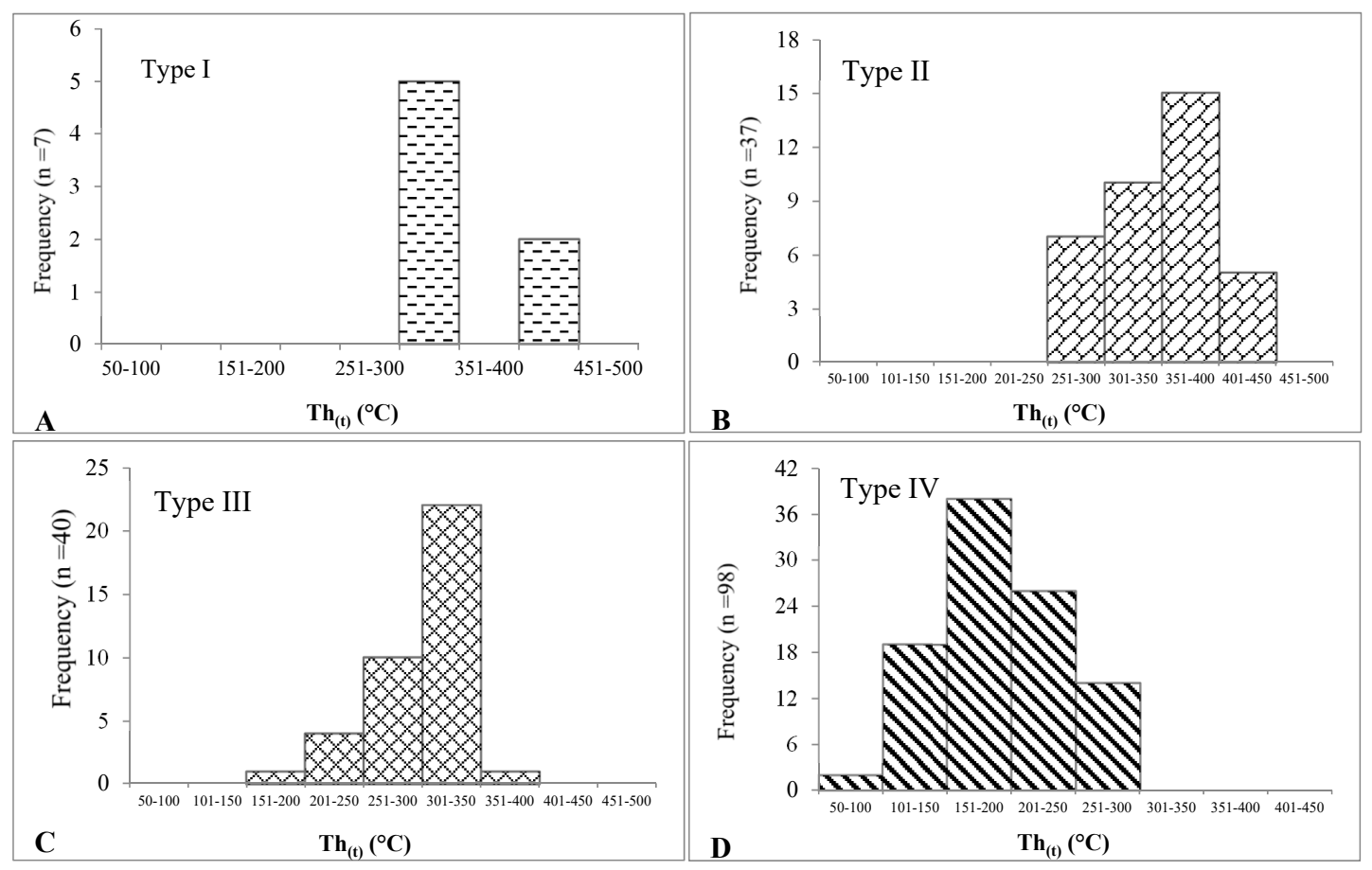

Figure 18. Histograms of total homogenization temperatures $\left(\mathrm{Th}_{(\mathrm{t})}\right)$ vs. frequency, in primary $(\mathrm{A}-\mathrm{C})$ and secondary (D) fluid inclusions.

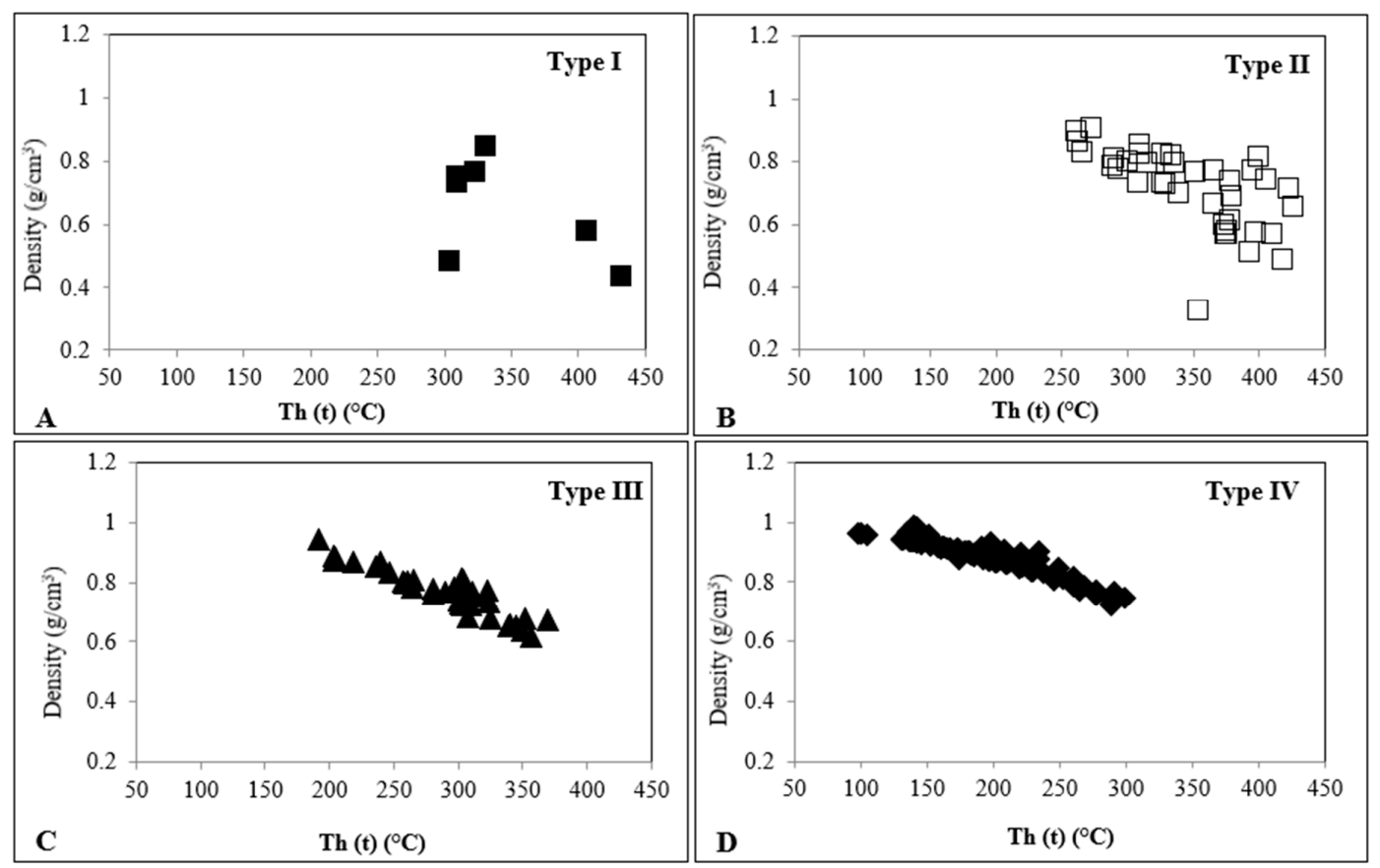

Figure 19. Chart showing the relation between total homogenization temperature vs. density calculation for primary (A-C) and secondary fluid inclusions (D). 

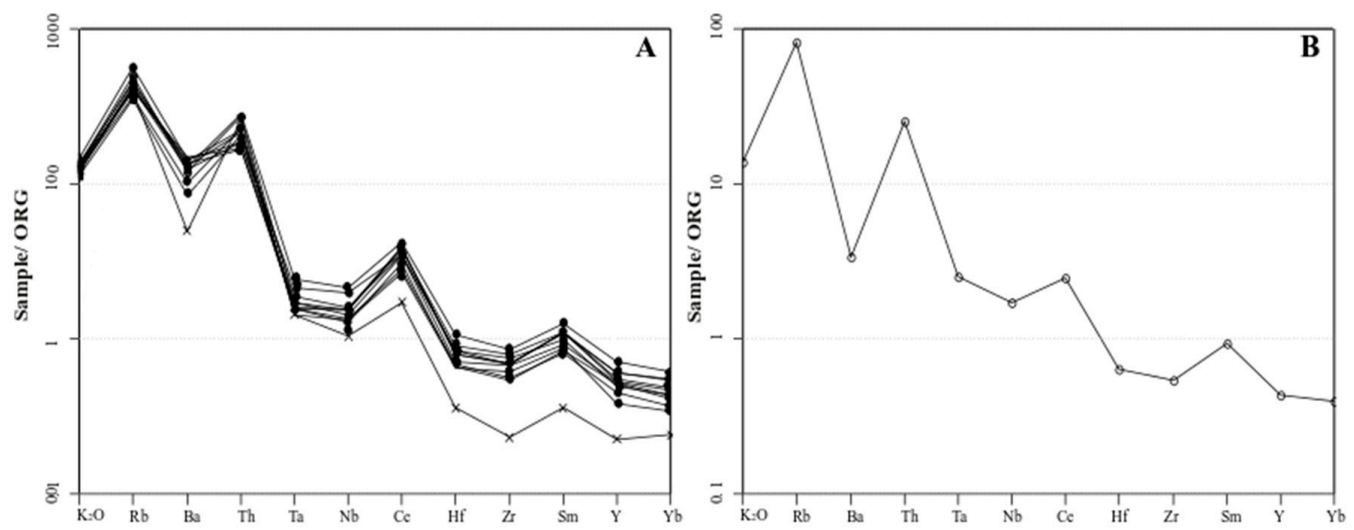

Figure 20. Ocean-ridge granite (ORG) normalized diagram of granite samples from the Tocantinzinho deposit: (A) and pattern for volcanic arc granites; (B) based on the normalization values of Pearce et al. [43]. Unaltered granite (๑), felsic dike (X) and standard representation (o).

In the primordial mantle-normalized diagram [46], with samples ordered by increasing compatibility with the mantle source (Figure 21), granite samples exhibit pronounced negative anomalies of $\mathrm{Ba}, \mathrm{Nb}, \mathrm{Ti}, \mathrm{Sr}$ and $\mathrm{P}$; positive anomalies of $\mathrm{Pb}, \mathrm{K}, \mathrm{Rb}, \mathrm{Sm}$ and $\mathrm{Nd}$; and absence of anomalies of $\mathrm{Y}$ and $\mathrm{Yb}$, which suggests the absence of residual source material. Similarly, the rhyolitic dike sample exhibits negative anomalies of $\mathrm{Ba}, \mathrm{Nb}, \mathrm{P}$ and $\mathrm{Ti}$; positive anomalies of $\mathrm{Pb}$ and $\mathrm{Nd}$; and no anomaly of $Y$, which is similar to the results for granite. The chemical characteristics of both rock types suggest that the fractional crystallization was crucial in the magmatic evolution of these rocks and was most likely responsible for the progressive enrichment in $\mathrm{Rb}$ and impoverishment in $\mathrm{Ba}$, $\mathrm{Sr}$ and V [43]. K-feldspar fractionation from the felsic liquid during the crystallization of the granite enabled the enrichment in $\mathrm{Rb}$ and impoverishment in $\mathrm{Ba}$ and $\mathrm{Sr}$. Granite rocks that are unaltered or have a low degree of hydrothermal alteration in Tocantinzinho do not exhibit mafic enclaves and have a negative anomaly in $\mathrm{Eu}$, an absence of negative anomaly in $\mathrm{Y}$ and low $\mathrm{Sr}$ content, which suggests that pressure conditions were lower than $10 \mathrm{~kb}$. Garnet is absent and residual plagioclase is more abundant, indicating crustal evolution, probably due to fractional crystallization [52].

Based on the petrographic, chemical and fluid inclusion data obtained in this research, we suggest that the studied hydrothermal fluid may have a magmatic origin and a strong influence from meteoric fluids. The I-type $1.98 \mathrm{Ga}$ monzogranite of the Tocantinzinho deposit probably played a fundamental role in the mineralization process, either as a source of the mineralizing fluids or as a source of fluids and metals. One possibility is the introduction of gold during the generation of the oxidized calc-alkaline magma, starting from the partial melting of the subducted oceanic plate or from the metasomatized mantle wedge or even from the melting of the crust [53].

The coexistence of fluid inclusions homogenizing to vapor and to liquid suggests that the mineralizing fluid may have been subjected to boiling, which may have been one cause of the early ore deposition. As the main mineralization process occurred during the phyllic alteration stage and considering the obtained fluid inclusions characteristics and temperatures, the mixing of magmatic fluid with later meteoric water is the most probable mechanism of ore deposition in the area. It is possible to infer from the ore paragenesis and fluid characteristics that the mineralizing fluids contained dissolved sulfur species and that gold transportation was conducted mainly by bisulfide complexes, for example, $\mathrm{Au}(\mathrm{HS})_{2}{ }^{-}$[54-57].

Mello [6] and Juras et al. [7] proposed that the Tocantinzinho deposit should be classified as intrusion-related gold deposits. Thompson et al. [58]. Villas et al. [8] and Santiago et al. [22] classified this deposit as reduced intrusion-related gold systems (RIRGS), based on the Hart [59] description. 




Figure 21. Primordial mantle-normalized element variation diagram [46] of the following samples: unaltered granite $(\bullet)$ and felsic dike $(X)$.

The geological, petrological and fluid inclusion characteristics obtained in this study for the Tocantinzinho deposit are suggestive of a magmatic-hydrothermal gold-only deposit genetically related to an oxidized calc-alkaline monzogranite, with the main mineralization stage host in a stockwork system. Ore deposition occurred during microclinization and, mainly, in the phyllic hydrothermal stages; hydrothermal magnetite occurred during paragenesis to the ore; and $\mathrm{H}_{2} \mathrm{O}-\mathrm{NaCl}$ mineralizing fluids with main homogenization temperatures ranging from 300 to $430{ }^{\circ} \mathrm{C}$. These characteristics preclude the classification of the deposit as a reduced intrusion-related gold system (RIRGS).

In comparisons with other similar deposits and classifications in Brazil and worldwide, the Tocantinzinho deposit has more similarities with magmatic-hydrothermal ore deposits, classified as porphyry gold deposits, than with other granite-host deposit types (Table 6) [53,60,61]. Similar interpretations were proposed for deposits associated with Precambrian granite magmatism and volcanism in the Tapajós Mineral Province [15,62-64] and in the Juruena-Teles Pires Province [20,65]. The deposit lacks many typical characteristics of the Phanerozoic porphyry-type deposit, such as the classic hydrothermal alteration pattern and high salinity mineralizing fluid, which could be due to its present erosion level. Because of the lack of these complete characteristics, the deposit could be described using a more general expression, such as oxidized calc-alkaline granite-related gold deposit (OCAGG). To avoid confusion or misunderstanding and as a Proterozoic deposit does not preserve all original characteristics as a Phanerozoic deposit does, especially its superficial features and paragenesis, we prefer to classify the Tocantinzinho deposit as a porphyry-style gold deposit. The same description can be applied to other similar Paleoproterozoic granite-related gold deposits in the Tapajós and Juruena-Teles Pires Amazonian gold provinces [20]. 
Table 6. The main features of Tocantinzinho deposit compared to porphyry gold deposits and reduced-intrusion-related gold-systems deposits (RIRGIS). The parameters for porphyry gold deposit are from Sillitoe and Sinclair [60,66,67]; the parameters for RIRGIS are according to Hart [59].

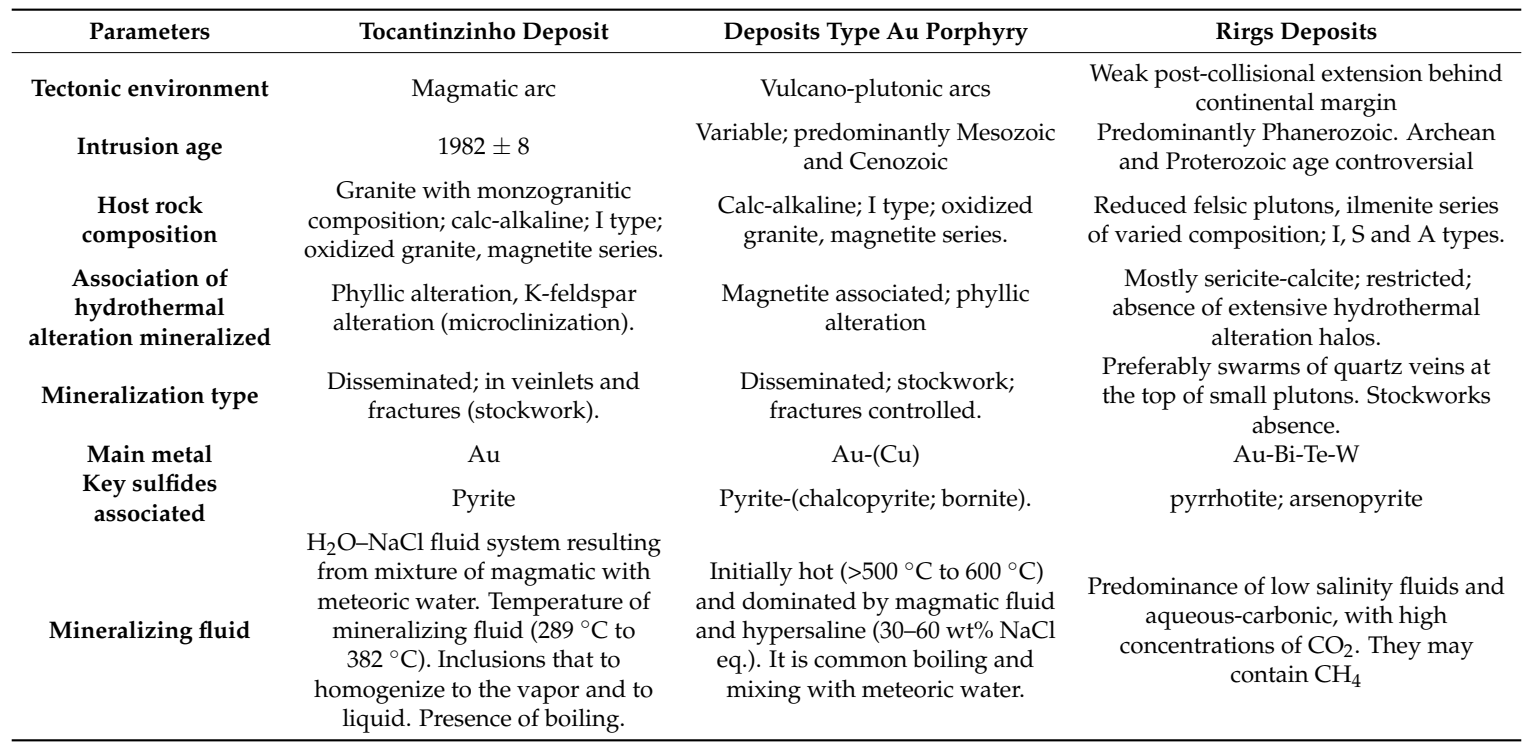

\section{Conclusions}

The Tocantinzinho gold deposit in the Tapajós Mineral Province, Amazonia, Brazil, is a magmatic-hydrothermal stockwork, with ore in veinlets disseminated in the rock without preferential orientation. It is spatially and genetically related to the hydrothermal alteration of a 1.98 Ga I-type monzogranite, interpreted as an early manifestation of the intrusive Creporizão Suite, with calc-alkaline characteristics, of the magnetite series, located in a magmatic arc tectonic setting.

The overall characteristics of the deposit, including the style of mineralization, ore paragenesis and magmatic-hydrothermal system, are consistent with a predominantly magmatic source for the mineralizing fluid, which evolved possibly initially by boiling, followed by mixing with meteoric water during its ascent, causing gold precipitation.

Tocantinzinho's geological, petrological and fluid inclusion features, in comparison with other intrusion-related deposits described in the literature, allow us to suggest that the deposit is similar to porphyry-type Au deposits [66,67] and could be referred to using the more descriptive and general term oxidized calc-alkaline granite-related gold deposit (OCAGG). Instead, the preference herein is to classify the Tocantinzinho gold deposit as a porphyry-style gold deposit, as the lack of all of the classic Phanerozoic porphyry-type deposits characteristics can be due, in part, to its deep erosion level. The same description can be applied to other similar Paleoproterozoic granite-related gold deposits in the Tapajós and Juruena-Teles Pires Amazonian gold provinces.

Further studies are needed to more accurately characterize all the physicochemical conditions of the mineralization and to understand the role that the monzogranite and the dikes of basaltic composition played as metal or ligand sources. The Tocantinzinho deposit characteristics reinforce the importance of the Tapajós and Juruena-Teles Pires provinces for containing disseminated oxidized calc-alkaline granite-related gold deposits in Southern Amazonia. The data obtained can be used to elaborate and guide prospection models in the region and in similar Proterozoic terrains.

Author Contributions: A.A.C.L. performed the analyzes, interpreted and produced much of the data present in the manuscript; M.A.M. conceived and coordinated the research and helped in the interpretation of analyzed samples and the final data; A.A.C.L wrote the paper; M.A.M. participated in the discussion and wrote the paper.

Funding: This study was financially supported by CAPES (Coordenação de Aperfeiçoamento de Pessoal de Nível Superior) (scholarship for the first author) and by CNPq (Conselho Nacional de Desenvolvimento Científico e Tecnológico) for the second author. 
Acknowledgments: The authors would like to thank the University of Brasília (Universidade de Brasília; UnB) for the physical and laboratorial support; CAPES (Coordenação de Aperfeiçoamento de Pessoal de Nível Superior); the Federal University of Pará (Universidade Federal do Pará; UFPA) for the initial support; and the mining companies Brazauro Resources Corporation and Eldorado Gold Corporation for the logistical support and for providing extremely relevant data for conducting the research. We are also indebted to the reviewers for their critical comments and constructive suggestions.

Conflicts of Interest: The authors declare no conflict of interest.

\section{References}

1. Coutinho, M.G.d.N. (Ed.) Provincia Mineral do Tapajós: Geologia, Metalogenia e Mapa Previsional Para Ouro em SIG; CPRM: Rio de Janeiro, Brazil, 2008; p. 420.

2. Barros, M.A.S.; Barros, A.J.P.; Santos, J.O.S.; Rocha, M.L.B.P. Extension of the Tapajós Domains to the Alta Floresta Gold Province: Evidence from U-Pb SHRIMP ages of the Nhandu Intrusive Suite at 1962 and 1967 Ma. In Proceedings of the $14^{\circ}$ Simpósio de Geologia da Amazônia, Belém, Pará, Brazil, 27 September-1 October 2015; v. CD-ROM.

3. Tassinari, C.C.G.; Macambira, M.J.B. Geochronological provinces of the Amazonian Craton. Episodes 1999, $22,174-186$.

4. Santos, J.O.S.; Hartmann, L.A.; Gaudette, H.E.; Groves, D.I.; Almeida, M.E.; McNaughton, N.J.; Fletcher, I.R. A new understanding of the provinces of the Amazon Craton based on integration of filed mapping and $\mathrm{U}-\mathrm{Pb}$ and Sm-Nd geochronology. Gondwana Res. 2000, 3, 453-488. [CrossRef]

5. Juliani, C.; Vasquez, M.L.; Klein, E.L.; Villas, R.N.N.; Misas, C.M.E.; Santiago, E.S.B.; Monteiro, L.V.S.; Carneiro, C.d.C.; Fernandes, C.M.D.; Usero, G. Metalogênese da Província Tapajós. In Metalogênese das Províncias Tectônicas Brasileiras; Da Silva, G., Da Rocha Neto, M.B., Jost, H., Kuyumjian, R.M., Eds.; CPRM: Belo Horizonte, Brazil, 2014; p. 589.

6. Mello, R.B. A Preliminary Assessment of the Tocantinzinho Gold Project, Tapajós Gold District, Pará State, Brazil-Three Million tons/year Scenario; Brazauros Resources Corporation: Nova Lima, Brazil, 2007.

7. Juras, S.; Gregersen, S.; Alexander, R. Technical Report for the Tocantinzinho Gold Project, Brazil; Eldorado Gold Corporation: Vancouver, BC, Canada, 2011.

8. Villas, R.N.N.; Santiago, E.S.B.; Castilho, M.P. Contexto geológico, estudos isotópicos (C, O e Pb) e associação metálica do depósito aurífero Tocantinzinho, domínio Tapajós, Província Tapajós-Parima. Rev. do Instituto de Geociências 2013, 13, 119-138. [CrossRef]

9. Dreher, A.M.; Vlach, S.R.F.; Martini, S.L. Adularia associated with epithermal gold veins in the Tapajós Mineral Province, Pará State, northern Brazil. Rev. Bras. Geocienc. 1998, 28, 397-404. [CrossRef]

10. Faraco, M.T.L.; Carvalho, J.M.d.A.; Klein, E.L. Carta Metalogenética da Província Aurífera do Tapajós. In Contribuições à Geologia da Amazônia; Costa, M.L., Angélica, R.S., Eds.; SBG-NO: Belém, Brazil, 1997; pp. 423-437.

11. Klein, E.L.; Vasquez, M.L.; Rosa Costa, L.T.; Carvalho, J.M.A. Geology of Paleoproterozoic gneiss- and granitoid-hosted gold mineralization in southern Tapajós gold province, Amazonian Craton, Brazil. Int. Geol. Rev. 2002, 44, 544-558. [CrossRef]

12. Jacobi, P. The discovery of epithermal Au-Cu-Mo Proterozoic deposits in the Tapajós Province, Brazil. Rev. Bras. Geocienc. 1999, 29, 277-279. [CrossRef]

13. Nunes, C.M.D. Caracterização de um Sistema Epitermal High-Sulfidation Paleoproterozóico na Província Aurífera do Tapajós, Pará. Dissertação de Mestrado, Universidade de São Paulo, São Paulo, Brazil, 2001.

14. Lamarão, C.N. Geoquímica, Petrologia e Geocronologia das Associações Magmáticas da Região de Vila Riozinho, Província Aurífera do Tapajós, Sudeste do Estado do Pará. Ph.D. Thesis, Universidade Federal do Pará, Belém, Pará, Brazil, 2001.

15. Juliani, C.; Corrêa Silva, R.H.; Monteiro, L.V.S.; Bettencourt, J.S.; Nunes, C.M.D. The Batalha Au-Granite system-Tapajós Province, Amazonian Craton, Brazil: Hydrothermal alteration and regional implication. Precambrian Res. 2002, 119, 225-256. [CrossRef]

16. Juliani, C.; Rye, R.O.; Nunes, C.M.D.; Silva, R.H.C.; Monteiro, L.V.S.; Neumann, R.; Alcover Neto, A.; Bettencourt, J.S.; Snee, L.W. Paleoproterozoic high-sulfidation mineralization in the Tapajós Gold Province, Amazonian craton, Brazil: Geology, mineralogy, alunite argon age and stable isotopes constraints. Chem. Geol. 2005, 215, 95-125. [CrossRef] 
17. Borges, R.M.K.; Dall' Agnol, R.; Lamarão, C.N.; Figueiredo, M.A.B.M.; Leite, A.A.d.S.; Barros, C.E.d.M.; Costi, H.T. Petrografia, química mineral e processos hidrotermais associados ao depósito de ouro São Jorge, Província Aurífera do Tapajós, Cráton Amazônico. Revista Brasileira de Geociências 2009, 39, 375-393. [CrossRef]

18. Veloso, A.S.R.; Santos, M.D. Geologia, petrografia e geocronologia das rochas do depósito aurífero Ouro Roxo, Província Tapajós, Jacareacanga (PA), Brasil. Braz. J. Geol. 2013, 43, 22-36. [CrossRef]

19. Assunção, R.F.S.; Klein, E.L. The Moreira Gomes deposit of the Cuiú-Cuiú goldfield: Fluid inclusions and stable isotope constraints and implications for the genesis of granite-hosted gold mineralization in the Tapajós Gold Province, Brazil. J. South Am. Earth Sci. 2014, 49, 85-105. [CrossRef]

20. Moura, M.A.; Botelho, N.F. Granite-Related Paleoproterozoic, Serrinha Gold Deposit, Southern Amazonia, Brazil: Hydrothermal Alteration, Fluid Inclusion and Stable Isotope Constraints on Genesis and Evolution. Econ. Geol. 2006, 101, 585-605. [CrossRef]

21. Santiago, E.S.B. Rochas Hospedeiras, Alteração Hidrotermal e Avaliação do Balanço Geoquímico de Massa do Depósito Aurífero Tocantinzinho, Província do Tapajós-PA. Master's Thesis, Instituto de Geociências, Universidade Federal do Pará, Belém, Pará, Brazil, 2012.

22. Santiago, E.S.B.; Villas, R.N.N.; Ocampo, R.C. The Tocantinzinho gold deposit, Tapajós province, state of Pará: Host granite, hydrothermal alteration and mineral chemistry. Braz. J. Geol. 2013, 43, 185-208. [CrossRef]

23. Queiroz, J.D.S.; Villas, R.N. Estudo dos fluidos hidrotermais relacionados ao depósito Tocantinzinho, Província Aurífera do Tapajós (PA), com base em inclusões fluidas. In Contribuições à Geologia da Amazônia, 1st ed.; Sociedade Brasileia de Geologia—Núcleo Norte: Belém, Pará, Brazil, 2015; Volume 9, pp. 93-117.

24. Borgo, A.; Biondi, J.C.; Chauvet, A.; Ocampo, R. Depósito de ouro Tocantinzinho (Pará): análise preliminar do controle das alterações hidrotermais e da deformação sobre a mineralização. In Proceedings of the Anais do $47^{\circ}$ Congresso Brasileiro de Geologia, Salvador, Bahia, Brazil, 21-26 September 2014.

25. Cathelineau, M. Cation site occupancy in chlorites and illites as a function of temperature. Clay Miner. 1998, 23, 471-485. [CrossRef]

26. Bodnar, R.J. Introduction to fluid inclusions. In Fluid inclusions: Analysis and interpretation; Samson, I., Anderson, A., Marshall, D., Eds.; Mineralogical Association of Canada: Quebec, QC, Canada, 2003; Volume 32, pp. 1-8.

27. Bodnar, R.J. Introduction to aqueous-electrolyte fluid inclusions. In Fluid Inclusions: Analysis and Interpretation; Samson, I., Anderson, A., Marshall, D., Eds.; Short Course Series; Mineralogical Association of Canada: Quebec, QC, Canada, 2003; Volume 32, pp. 81-100.

28. Santos, J.O.S.; Groves, D.I.; Hartmann, L.A.; Moura, M.A.; McNaughton, N.J. Gold deposits of the Tapajós and Alta Floresta Domains, Tapajós-Parima orogenic belt. Amazon craton, Brazil. Miner. Depos. 2001, 36, 453-488. [CrossRef]

29. Tassinari, C.C.G.; Macambira, M.J.B. A evolução tectônica do Cráton Amazônico. In Geologia do Continente Sulamericano: Evolução da obra de Fernando Flávio Marques de Almeida; Neto, V.M., Barorelly, A., Carneiro, C., Brito-Neves, B., Eds.; Ed. Beca: São Paulo, Brazil, 2004; pp. 471-485.

30. Vasquez, M.L.; Rosa-Costa, L.T.; Silva, C.M.G.; Klein, E.L. Compartimentação tectônica. In Geologia e Recursos Minerais do Estado do Pará: Sistema de Informações Geográficas e SIG: texto explicativo dos mapas Geológico e Tectônico e de Recursos Minerais do Estado do Pará. Escala 1:1.000.000; Vasquez, M.L., Rosa-Costa, L.T., Eds.; CPRM—Serviço Geológico do Brasil: Belém, Brazil, 2008.

31. Santos, J.O.S.; Van Breemen, O.T.; Groves, D.I.; Hartmann, L.A.; Almeida, M.E.; McNaughton, N.J.; Fletcher, I.R. Timing an evolution of multiple Paleoproterozoic magmatic arcs in the Tapajós Domain, Amazon Craton: Constraints from SHRIMP and TIMS zircon, baddeleyite and titanite U-Pb geochronology. Precambrian Res. 2004, 131, 73-109. [CrossRef]

32. Ricci, P.S.F.; Vasques, M.L.; Santos, A.; Klein, E.L.; Jorge João, X.S.; Martins, R.C. Suíte Intrusiva CreporizãoProvíncia do Tapajós: Proposta e critérios de definição. SBG-NO Simp. Geol. Amaz. 1999, 6, 519-522.

33. Lamarão, C.N.; Dall'Agnol, R.; Pimentel, M.M. Nd isotopic composition of Paleoproterozoic volcanic rocks of Vila Riozinho: Implications for the crustal evolution of the Tapajós gold province, Amazon craton. J. South Am. Earth Sci. 2005, 18, 277-292. [CrossRef]

34. Lamarão, C.N.; Dall'agnol, R.; Lafon, J.M.; Lima, E.F. Geology, geochemistry and Pb-Pb zircon geochronology of the Paleoproterozoic magmatism of Vila Riozinho, Tapajós Gold Province Amazonian Craton, Brazil. Precambrian Res. 2002, 119, 189-223. [CrossRef] 
35. Juliani, C.; Fernandes, C.M.D.; Carneiro, C.C.; Misas, C.M.E.; Lagler, B.; Aguja-Bocanegra, M.A.; Tokashiki, C.C. Controle tectônico e eventos magmáticos associados às mineralizações epitermais, do tipo pórfiro e IOCG Paleoproterozóicas na parte sul do Cráton Amazônico e seu potencial de prospectividade. In Proceedings of the Anais do $3^{\circ}$ Simpósio Brasileiro de Metalogenia, Gramado, Rio Grande do Sul, Brazil, 2-5 June 2003.

36. Teixeira, N.A.; Matos, F.M.V.; Ganade, C.E.; Klein, E.L.; Dreher, A.M.; Tavares, F.M.; Leandre, D.C.; Porto, F. Carajás and Tapajós Mineral Province: Cratonic and pericratonic Lithosphere keel metallogeny. In Proceedings of the Anais do $14^{\circ}$ Simpósio de Geologia da Amazônia, Belém, Pará, Brazil, 27 September-1 October 2015.

37. Borgo, A.; Biond, J.C.; Chauvet, A.; Bruguier, O.; Monié, P.; Baker, T.; Ocampo, R.; Friendman, R.; Mortensen, J. Geochonological, geochemical and petrographic constrain on the Paleoproterozoic Tocantinzinho gold deposit (Tapajós Gold Province, Amazonian Craton-Brazil): Implications for timing, regional evolution and deformation style of its host rocks. J. South Am. Earth Sci. 2017, 75, 92-115. [CrossRef]

38. Castro, A.A.; Villas, R.N.N.; Pereira, E.L. Geologia e Alteração Hidrotermal do Depósito Aurífero Tocantinzinho, Província Aurífera do Tapajós. In Proceedings of the Anais do $45^{\circ}$ Congresso Brasileiro de Geologia, Belém, Pará, Brazil, 26 September-1 October 2010.

39. Castro, A.A. Gênese do Depósito de ouro Tocantinzinho, Província Mineral Tapajós (Pará): Evidências a partir de dados de Geologia, Petrologia e Inclusões Fluidas. Dissertação de mestrado, Instituto de Geociências da Universidade de Brasília, Brasília, Distrito Federal, Brazil, 15 October 2015.

40. Streckeisen, A. A classification and nomenclature of volcanic rocks, lamprophyres and melilitic rocks. Recommendations and suggestion of the IUGS on the Systematic of igneous Rocks. Geol. Boulder 1979, 7, 331-335. [CrossRef]

41. Shand, S.J. Eruptive rocks: Their Genesis, Composition, Classification, and Their Relation to Ore-Deposits with a Chapter on Meteorite; John Wiley \& Sons: New York, NY, USA, 1943.

42. Pearce, J.A.; Harris, N.B.W.; Tindle, A.G. Trace Element Discrimination Diagrams for the Tectonic Interpretation of Granitic Rocks; Department of Earth Sciences, The Open University: Milton Keynes, Bucks, UK, 1984.

43. Nakamura, N. Determination of REE, Ba, Fe, Mg, $\mathrm{Na}$, and $\mathrm{K}$ in carbonaceous and ordinary chondrites. Geochim. Cosmochim. Acta 1974, 38, 757-775. [CrossRef]

44. Le Bas, M.J.; Keller, J.; Tao, K.; Wall, F.; Williams, C.T.; Peishan, Z. Carbonatite dykes at Bayan Obo, Inner Mongolia, China. Mineral. Petrol. 1992, 46, 195-228. [CrossRef]

45. Pearce, J.A.; Cann, J.R. Tectonic setting of basic volcanic rocks determined using trace element analyses. Earth Planet. Sci. Lett. 1973, 19, 290-300. [CrossRef]

46. Sun, S.S.; McDonough, W.F. Chemical and isotopic systematics of oceanic basalts; implications for mantle composition and processes. In Magmatism in the Ocean Basins; Saunders, A.D., Norry, M.J., Eds.; Geological Society of London: London, UK, 1989; Volume 42, pp. 313-345.

47. Carlson, C.A. Spatial distribution of ore deposits. Journal Article. Geol. Soc. Am. 1991, 19, 111-114.

48. Queiroz, J.D.S. Estudos dos fluidos hidrotermais relacionados ao Depósito Tocantinzinho, Província Mineral Tapajós, com base em inclusões fluidas. In Trabalho de Conclusão de Curso (TCC); Instituto de Geociências, Universidade Federal do Pará: Belém, Pará, Brazil, 2013.

49. de Caritat, P.; Hutcheon, I.; Walshe, J.L. Chlorite geotermometry: A review. Clay Clay Miner. 1993, 41, $219-239$. [CrossRef]

50. Shepherd, T.J.; Ranking, A.H.; Alderton, D.H.M. A Practical Guide to Fluid Inclusion Studies; Blackie \& Son Ltd.: Glasgow, UK, 1985; 239p.

51. Goldstein, R.H.; Reynolds, T.J. Systematics of fluids inclusions in diagenetic minerals. Soc. Sediment. Geol. Short Course 1994, 31, 199.

52. Wyborn, L.A.I.; Wyborn, D.; Warren, R.G.; Drummond, B.J. Proterozoic granite types in Australia: Implications for lower crust composition, structure and evolution. Trans. R. Soc. Edinburgh Earth Sci. 1992, 83, 201-209. [CrossRef]

53. Hedenquist, J.W.; Lowenstern, J.B. The role of magmas in the formation of hydrothermal ore deposits. Nature 1994, 370, 519-527. [CrossRef]

54. Gammons, C.H.; Williams-Jones, A.E. Chemical mobility of gold in the epithermal environment. Econ. Geol. 1997, 92, 45-59. [CrossRef] 
55. Williams-Jones, A.E.; Samson, I.M.; Linnen, R.L. Fluid evolution and its role in the genesis of the granite-related Madeleine copper deposit, Gaspé, Quebec. Econ. Geol. 1989, 84, 1515-1524. [CrossRef]

56. Pokrovski, G.S.; Kokha, M.A.; Guillaume, D.; Borisova, A.Y.; Gisquet, P.; Hazemann, J.-L.; Lahera, E.; Del Net, W.; Proux, O.; Testemale, D.; et al. Sulfur radical species form gold deposits on Earth. Proc. Natl. Acad. Sci. USA 2015, 112, 13484-13489. [CrossRef]

57. Thigub, A.L.; Tagirov, B.R.; Kvashnima, K.O.; Lafuerza, S.; Filiomonova, O.N.; Nickolsky, M.S. Experimental Determination of Gold Speciation in Sulfide-Rich Hydrothermal Fluids Under a Wide Range of Redox Conditions. Chem. Geol. 2017, 471, 52-64.

58. Thompson, J.F.H.; Sillitoe, R.H.; Baker, T.J.R.; Mortensen, J.K. Intrusion-related gold deposits associated with tungsten-tin provinces. Miner. Depos. 1999, 34, 323-334. [CrossRef]

59. Hart, C.J.K. Reduced intrusion-related gold systems. In Mineral deposits of Canada: A Synthesis of Major Deposit Types, District Metallogeny, the Evolution of Geological Provinces, and Exploration Methods; Goodfellow, W.D., Ed.; Geological Association of Canada, Mineral Deposits Division: St. John's, NL, Canada, 2007; Volume 5, pp. 95-112.

60. Sinclair, W.D. Porphyry deposits. In Mineral Deposits of Canada: A Synthesis of Major Deposit-Types, District Metallogeny, the Evolution of Geological Provinces, and Exploration Methods; Goodfellow, W.D., Ed.; Geological Association of Canada, Mineral Deposits Division: St. John's, NL, Canada, 2007; Volume 5, pp. 223-243.

61. Pirajno, F. Hydrothermal Processes and Mineral Systems; Springer: Perth, WA, Australia, 2009; p. 1273.

62. Echeverri-Misas, C.M.; Juliani, C.; Aguja-Bocanegra, M.A.; Monteiro, L.V.S.; Tokashiki, C.C. Mineralizações High- e Low-Sulfidation e do tipo pórfiro na porção sul da Província Mineral do Tapajós. In Proceedings of the $14^{\circ}$ Simpósio de Geologia da Amazônia, Marabá, Pará, Brazil, 27 September-1 October 2015.

63. Aguja-Bocanegra, M.A.; Juliani, C.; Tokashiki, C.C.; Echeverri-Misas, C.M.; Monteiro, L.V.S.; Lagler, B. Sistema Epitermal low-sulfidaton e do tipo pórfiro paleoproterozóicos na Província Mineral do Tapajós (PMT). In Proceedings of the $14^{\circ}$ Simpósio de Geologia da Amazônia, Marabá, Pará, Brazil, 27 September-1 October 2015.

64. Bettencourt, J.S.; Juliani, C.; Xavier, R.P.; Monteiro, L.V.S.; Bastos Neto, A.C.; Klein, E.L.; Assis, R.R.; Leite, W.B.; Moreto, C.P.N.; Dias, F.C.M.; et al. Metallogenetic systems associated with granitoid magmatism in the Amazonian Craton: an overview of the present level of understanding and exploration significance. J. South Am. Earth Sci. 2016, 68, 22-49. [CrossRef]

65. Silva, M.d.G.d.; Abram, M.B. Metalogenia da Província Aurífera Juruena-Teles Pires, Mato Grosso; CDD 553.1; CPRM (Convênio CPRM/SICME): Goiânia, Brazil, 2008; ISBN 978-85-7499-060-6.

66. Sillitoe, R.H. Gold-rich porphyry deposits: Descriptive and genetic models and their role in exploration and Discovery. Rev. Econ. Geol. 2000, 13, 315-345.

67. Sillitoe, R.H. Porphyry copper systems. Econ. Geol. 2010, 105, 3-41. [CrossRef] 